University of Rhode Island

DigitalCommons@URI

Open Access Master's Theses

1972

\title{
Land Development Policy on the Local, State, and National Levels: A Case Study of Narragansett, Rhode Island
}

Thomas William Fennessey

University of Rhode Island

Follow this and additional works at: https://digitalcommons.uri.edu/theses

\section{Recommended Citation}

Fennessey, Thomas William, "Land Development Policy on the Local, State, and National Levels: A Case Study of Narragansett, Rhode Island" (1972). Open Access Master's Theses. Paper 595.

https://digitalcommons.uri.edu/theses/595

This Thesis is brought to you for free and open access by DigitalCommons@URI. It has been accepted for inclusion in Open Access Master's Theses by an authorized administrator of DigitalCommons@URI. For more information, please contact digitalcommons-group@uri.edu. 


\section{LAND DEVELOPMENT POLICY ON THE LOCAL, STATE, •} AND NATIONAL LEVELS

A CASE STUDY OF NARRAGANSETT, RHODE ISLAND

BY

THOMAS WILLIAM FENNESSEY

A Thesis Submitted in Partial Fulfillment of the Requirements for the Degree of Master of Community Planning

UNIVERSITY OF RHODE ISLAND 1972 


\title{
MASSTER OF COMMUNITY PLANNING THESIS
}

\author{
OF
}

THOMAS WILLIAM FENNESSEY

APPROVED:

Thesis Committee:

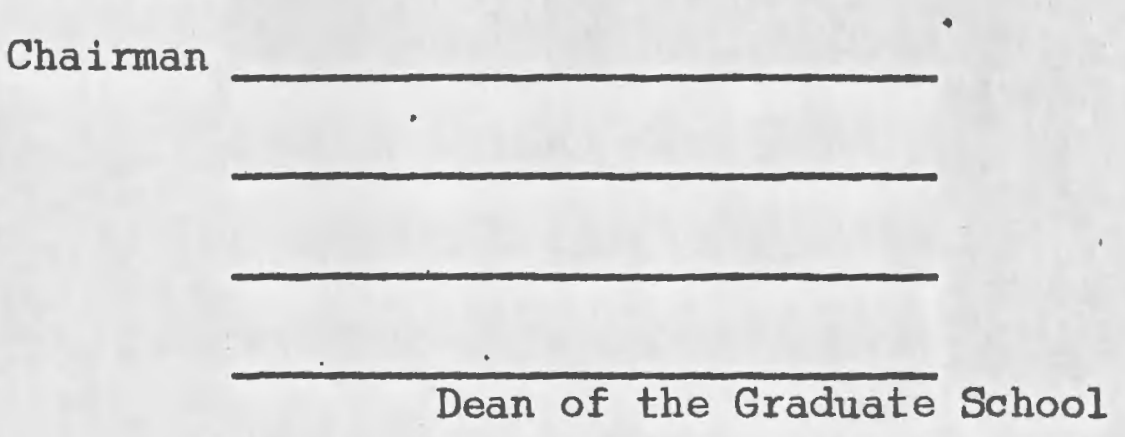

UNIVERSITY OF RHODE ISLAND

1972 


\section{- $\quad$ ABSTRACT}

The three primary purposes of this study are: to identify and assess existing land development policies in Narragansett, Rhode Island, to determine any deficiencies in those development policies, and to suggest possible future actions to remedy those deficiencies. Since these policies are not isolated from the dynamics of a growing eommunity, an analysis was also performed of such bastc data as land use, population, and housing to predict the effect these variables would have on the town's future development. The interrelationship of these three variables with land use policy was demonstrated.

The major land use policles of the Town were represented by the goals and objectives of the Comprehensive Community Plan, by the decisions of the Zoning and Platting Board of Review, by the existing zoning ordinance and its amendments, and by the proposed zoning ordinance. Accordingly, the Comprehensive Community Plan was reviewed in detall. The decisions of the Zoning and Platting Board of Review on variances from June of 1967 to March of 1972 were also studied in detail. An extensive review of the zoning 
ordinance and its amendments was undertaken from the time of the adoption of the ordinance in August of 1930 to January of 1972. An evaluation was made of the development implications of the proposed zoning ordinance.

Since land use legislation is strongly influenced by forces on both the state and national level, an integral element of the study was to consider proposed land use legislation in Rhode Island, in certain selected states, and in the nation as a whole. Accordingly, Chapter II deals exclusively with three areas of Rhode Island's land use program - existing legislation, legislation currently under development, and future legislation. The concluding Chapter reviews statewide land use provisions in Hawail, Vermont, Wisconsin, Massachusetts, and Maine, discusses the National Land Use Policy Act, identifies disadvantages of our current land use system, and posits future alternatives.

The major conclusions derived from this study are delineated below. The first six conclusions apply specifically to Narragansett, while the six remaining conclusions. are of a more general nature.

(1) Both seasonal and year-round population will continue to increase steadily in Narragansett and will exert a strong demand for additional housing units.

(2) Narragansett will be a fully developed 
TABLE OF CONTENTS

LIST OF TABLES

INTRODUCTION.

I. LAND DEVELOPMENT POLICY IN NARRAGANSETT,

RHODE ISLAND. ............................ 3

Population Growth............................ 4

Housing Growth............................ 6

Natural Features and Land Use ................. 9

Population Projection.......................... 11

Public Development Polićy..................... 15

Zoning Amendments.......................... 19

Rezonings................................ 22

Zoning and Platting Board of Review............. 26

Development Goals........................... 29

Proposed Zoning Ordinance...................... 34

Recent Development Trends..................... 37

II. EXISTING AND PROPOSED LAND DEVELOPMENT POLICIES

IN THE STATE OF RHODE ISLAND.................

Political Structure..........................

Relationship of Power of State and Local

Government ................................ 
Home Rule.............................. 45

State and Local Powers...................... 47

Existing Land Use Control Measures............. 49

Programs ¿Currently Under Development.............. 59

Proposed Laws and Programs.................... 63

III. TRENDS IN STATE AND NATIONAL LAND USE POLICY...... 71

Evolution of Land Use Controls................ 73

Critique of Zoning........................ 74

State Legislation Related to Land Use............ 76

National Land Use Pollcy Act................... 79

Model Land Development Code.................. 81

Plan for Bucks County, Pennsylvania............. 84

Directions in Land Use Planning............... 87

Implementation Measures..................... 89

BIBLIOGRAPHY.............................. 93 


\section{LIST OF TABLES}

Table

Page

1. Population Growth in Narragansett............. 5

2. Annual Residential Bullding Permits Issued

(From 1950 to 1971 )...................... 7

3. Narragansett Land Features .................. 10

4. Land Use Inventory ....................... 12

5. Lot Sizes in Residence Districts .............. 20

6. Types of Zone Changes Granted Over 5 Year

Periods..................................... 23

7. Decisions of Zoning and Platting Board of . Review from 1967-1972................... 28

8. Relationship of Zoning Districts.............. 35 
suburban community of between 15,000 and 20,000 people within the next 50 to 75 years.

- (3) The effect of amendments to the zoning ordinance in the form of increased lot sizes in residence districts will be to decrease the town's net population density.

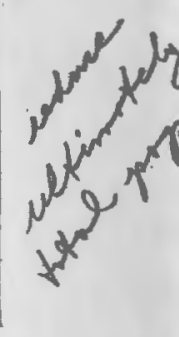

(4) The lack of sufficient business districts in the original zoning ordinance resulted in the dispersal of various businesses throughout the Town. Concentration of businesses in 3 or 4 specific areas would have prevented this.

(5) The number of review cases heard by the Zoning and Platting Board of Review was not large enough to have a major impact on the Town's overall development.

(6) With the exception of the rezoning of several areas of Narragansett to one acre minimum lot sizes, the effect the proposed zoning ordinance would have on the Town's future growth and development would not be significantly different from the effect the existing ordinance 
would have assuming it were to remain in force.

(7) The political and geographic structure of the State of Rhode Island is extremely advantageous to the implementation and administration of statewide land use controls.

(8) As yet, land development on a large scale such as new communities has not occurred in Rhode Island.

(9) Zoning is a restrictive land use control and does not provide the positive stimulus required for shaping desirable community development.

(10) Future land use reform will be of an evolutionary, not a revolutionary, nature.

(11) The thrust of recent land use legislation has been directed toward transferring responsibility for land use control from local government to state and national government.

(12) To achieve a more orderly land use guldance system, government on the local, state, and national levels must 
not only expand its current programs but also acquire additional authority to implement more ambitious and flexible programs. 


\section{ACKNOWLEDGMENTS}

In any study of an in depth nature the researcher owes a debt to the many individuals who have devoted their time and energy to increasing the knowledge in his or her particular area of interest. Consequently, I would like to acknowledge the work and research efforts of the authors cited in the bibliography. I would also like to acknowledge the co-operative and helpful staff of the Town Clerk's Office in Narragansett, particularly Mrs. Elvira Fayerweather, of whose kind assistance, I am sure, I was not the first to receive. Many thanks also to my thesis committee, Charles Downe, Douglas Johnson, and Albert Owens, for their patience and numerous suggestions which were incorporated into the body of the thesis. 


- INTRODUCTION

Modern, post industrial man inhabits a world of transient experiences, of kaleidoscopic sensations, and traumatic transitions. Admidst this turmoil might modern man long for the anthropologically primitive security of a Cro-Magnon's cave. Here, lived a truly fundamental man, linked closely to the earth, a creature of the forest as much as any other animal. The forest and the land were his reservoir of supply, shelter, and succorance - to be valued and not destroyed. In fact, he did not possess the power to subvert the environment with such tools as a rough hewn club and a paltry stone ax. Not so the case for modern man, who possesses the power of lethal environmental destruction made possible by numerous technological triumphs. Rational, technological modern man wrongly visualizes his destiny as separate from the earth and the land. In polluting the earth he severs his own umbilical cord and poisons his own embryo.

This study treats but one link in the chain of the earth's natural resources - the land on the surface of that earth - its use, appearance, and visual character. An underlying thread in the study hints that a basic conflict 
might exist between forces within the market economy and the fundamental structure of land use and property rights. If in fact a basic rift does exist here, the implications for the more encompassing environmental issues are indeed pessimistic. The real issue is that a health technology and a healthy economy may create a sick environment. 


\section{LAND DEVELOPMENT POLICY IN NARRAGANSETT, RHODE ISLAND}

In the late 1800's Narragansett, Rhode Island was both a quiet farming community and a famed summer resort. Since that peak period, its popularity as a summer resort has declined slightly. However, this once quiet. rural community is being transformed by 20 th century residential and commercial expansion. Narragansett's growth rate has been particularly pronounced since World War II. Primarily two factors have been responsible for this accelerated growth. Firstly, improved highway access to metropolitan Providence has made Narragansett an accessible and attractive community for year-round residence. Secondly, the community's unique land and seascape have influenced the growth of permanent population and have continued to attract a sizable influx of summer residents and tourists.

The purpose of this chapter will be to examine the effect of the town's rapid growth on land use and to assess the impact of public land use controls on the town's overall development. 


\section{Population Growth}

In general, population statistics provide a reliable yardstick by which to measure either the growth or decline of a community. Basic population statistics were available from both the U. S. Census and the special 1965 Census for the State of Rhode Island. However, a note of caution is called for when interpreting these basic statistics for a resort community such as Narragansett.

Census figures account for year round residents only and do not include the large influx of summer residents and tourists who stay in hotels or motels. Estimates of the Rhode Island Development Council indicate that in 1960, if summer residents and tourists were actually included, the total population increased by approximately 9,000 people or more than 3.5 times the year round population. ${ }^{1}$

Both of the above groups, summer tourists and summer residents, have had a significant effect on land use by stimulating the growth of private facilities such as: hotels, motels, bars, and restaurants and public facilities such as: bath houses, golf courses, and playgrounds. The impact which summer residents have had on land use is also significant and will be discussed in more detall under the

${ }^{1}$ Rhode Island Development Council, Land Use Analysis, Narragansett, Rhode Island (Providence: November 1962), p. 12 . 
section on Housing.

Population figures for year-round residents are available and are shown in Table I:

\section{TABLE I}

Population Growth in Narragansett and Rhode Island

\begin{tabular}{ccccc} 
& \multicolumn{2}{c}{ Narragansett } & \multicolumn{2}{c}{ Rhode Island } \\
Year & Population & \% Change & Population & \% Change \\
1900 & 1,523 & -- & 428,556 & -- \\
1910 & 1,250 & -17.9 & 542,610 & 26.5 \\
1920 & 993 & -12.5 & 604,397 & 11.4 \\
1930 & 1,258 & 26.7 & 687,497 & 13.7 \\
1940 & 1,560 & 16.1 & 713,346 & 3.8 \\
1950 & 2,288 & 46.7 & 791,896 & 11.0 \\
1960 & 3,444 & 50.5 & 859,488 & 8.5. \\
$1965^{\mathrm{a}}$ & 5,043 & - & $(46.4)^{\mathrm{C}}--$ & -- \\
$1970^{\mathrm{b}}$ & 7,138 & $107.3(41.5)^{\mathrm{C}} 949,723$ & 10.1
\end{tabular}

Source (except where noted): Rhode Island Development Council, Land Use Analysis, Narragansett, Rhode Island, Table III, p. 10.

${ }^{\mathrm{a}}$ Rhode Island Development Council, Comprehensive Community Plan, Narragansett, Rhode Island (Providence: March 1967), Table I, p. 5 .

$\mathrm{b}_{1970}$ U. S. Census Data.

${ }^{C}$ Percentage change based on 5 year intervals. 
Except for the census years 1910 and 1920, which showed that Narragansett lost population, percentage population increases have been significantly above State levels. The greatest growth for the town both on a percentage and an absolute number basis occurred between 1960 and 1970. In that tenyear period, population more than doubled. Population projections contained in the Comprehensive Plan performed in 1967 grossly underestimated the growth in this ten-year period and projected a population of between 6,200 and 6,300 people for $1970 .{ }^{2}$ The 1980 population projection of between 7,300 and 7,800 hundred was, in fact, almost attained in 1970 when the population reached 7,138 people.

Admittedly, predicting population levels with any degree of accuracy is a difficult task and Rhode Island Development Council projections were certainly conservative in this case. Since few factors indicate any possibility of a decline in the rate of growth of the town's population, a better estimate for the 1980 population of Narragansett would be in the vicinity of 10,000 people.

\section{Housing Growth}

In the period from 1950 to 1971 inclusive, bullding permits were issued in Narragansett for 3,260 new dwelling.

${ }^{2}$ Rhode Island Development Council, Comprehensive Community Plan, Narragansett, Rhode Island, Table I, p. 5. 
units. This figure includes seasonal as well as year-round units. An annual tabulation of building permits issued between 1950 and 1971 is shown in Table II:

\section{TABLE II}

Annual Residential Building Permits Issued ${ }^{a}$

$$
\text { (From } 1950 \text { to } 1971)^{\text {b }}
$$

\begin{tabular}{lrrr} 
Year & $\begin{array}{c}\text { Permits } \\
\text { Issued }\end{array}$ & Year & $\begin{array}{c}\text { Permits } \\
\text { Issued }\end{array}$ \\
\hline 1950 & 244 & 1961 & 93 \\
1951 & 162 & 1962 & 100 \\
1952 & 158 & 1963 & 128 \\
1953 & 191 & 1964 & 128 \\
1954 & 128 & 1965 & 166 \\
1955 & 139 & 1966 & 143 \\
1956 & 134 & 1967 & 147 \\
1957 & 148 & 1968 & 232 \\
1958 & 127 & 1969 & 146 \\
1959 & 98 & 1970 & 154 \\
1960 & 99 & 1971 & 195
\end{tabular}

TOTAL $\quad 3,260$

${ }^{a}$ New dwelling units only, including seasonal units.

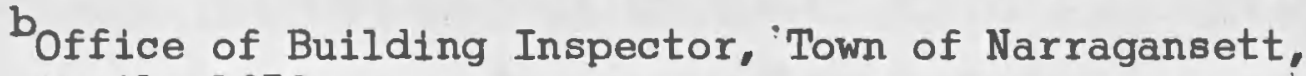
April, 1972.

Analysis of the table indicates that the number of permits issued for the eleven-year pertod from 1950 to $1960(1,628)$ 
is almost equal to the number of permits issued for the eleven-year period from 1961 to 1971 (1,632). Although an overlap occurrs in time spans between the annual building. permit data (which can be aggregated for ten or eleven year periods) and the ten year census data, certain deductions can still be made concerning the relationship of population growth and housing increase for those time periods. According to census data, between 1950 and 1960 the year-round population increased only $50.5 \%$ as compared to an increase of 107.3\% between 1960 and 1970. The greater percentage increase -between 1960 and 1970 is attributable to the greater number of year-round units built in that time and also to the conversion of seasonal homes to permanent residences.

Throughout the history of Narragansett, seasonal homes have always accounted for a large share of the community's housing stock. Data from the 1970 U. S. Census reflect the seasonal character of the community's housing supply. In 1970 , of 4,778 total units, approximately $24 \%$ of . the units $(1,994)$ were occupied on a temporary or seasonal basis.

From the building permit statistics shown in Table II, a projection can be made for the annual average number of building permits expected to be issued over the next five years. Based on the annual figures since 1965, a reasonable estimate of the average number of permits expected to be 
1ssued over the next five years would be between 150 and 175 . A major conclusion can be drawn from the data presented in-this section. As Narragansett continues to fulfill Its dual role as a bedroom suburb of the Providence SMSA and a summer resort of regional magnitude, the pressure of Increasing seasonal and year-round populations will exert a strong and steady demand on the housing market.

\section{Natural Features and Land Use}

In a Land Use Analysis for Narragansett performed in 1962, the major characteristics of the land were enumerated. In the ten years since 1962, land usage in the community has in all probability changed considerably, however, since recent land use data are not available, the 1962 data must be relied upon for the purposes of this study. Table III classifies the land into three main areas:

(1) land which may have been partially developed but which has moderate to severe restrictions for development.

(2) land which could be developed and has no severe restrictions for development, and

(3) land which has already been developed. The table indicates that of a total land area of 8,832 acres, almost 4,000 acres are suitable for some type of development. The land in this category is either gently rolling slopes 
wooded with small trees, woodland brush, or open land formerly devoted to agricultural use. Approximately thirty-one (31) per cent or almost 2,700 acres of the land has already been developed for some use.

\section{TABLE III}

Narragansett Land Features ${ }^{2}$

Characteristic Acres $\quad \begin{array}{r}\text { Percent of To,tal } \\ \text { Land Area.". }\end{array}$

Land with some development

restrictions

\begin{tabular}{lll} 
Imperfectly drained areas & 800 & 9 \\
Swamp or marshland & 650 & 7 \\
Slopes in excess of $15 \%$ & 100 & 1 \\
Rock Outcroppings & 110 & 1 \\
Hurricane Danger Areas & -490 & 6 \\
\multicolumn{2}{c}{ Subtotal } & 2,150 acres
\end{tabular}

Land with no severe development

restrictions

Land already developed

Total

3,991
2,691
8,832 acres $: \frac{31}{100}$

'Source: Rhode Island Development Council, Land Use Analysis, Table VII, p. 18.

One of the more prominent parameters to note in Table III is that nearly $70 \%$ of Narragansett's land area is 
undeveloped (as of the 1962 Land Use Survey). Although 24\% of this land has some development restrictions, $45 \%$ of the community's land area remains in the developable category. This large open, expansive land area, much of it along with shoreline, is one of the most positive factors in establishIng the charm and appeal of Narragansett.

A detailed breakdown showing the various land uses existing in the developed area is given in Table IV. Residential land accounts for the largest land user with over $50 \%$ of developed land in the residential category. Highways and governmental or institutional uses follow as the second and third most extensive land uses, respectively.

\section{Population Projection}

Using the data advanced in the previous section on

land use, an estimate can be made of the town's probable future population. In order to arrive at this estimate, the following assumptions will be made:

(1) the ratio of residential to total developed land will remain at :52,

(2) the average density for residential development will occur at three dwelling units/acre (based on an examination of the extent of the residential zones proposed in the new zoning ordinance).

(3) $70 \%$ of the new housing constructed will 
be of the year-round variety,

TABLE IV

Land Use Inventory ${ }^{a}$

\begin{tabular}{|c|c|c|c|}
\hline Use : & Acreage & $\begin{array}{l}\text { Developed } \\
\text { Land }\end{array}$ & $\begin{array}{l}\frac{\text { ent of }}{\text { Total Land }} \\
\text { Area }\end{array}$ \\
\hline Residential & 1400 & 52.0 & 15.9 \\
\hline Commercial & 35 & 1,3 & .4 \\
\hline Industrial & 6 & .2 & .1 \\
\hline Governmental \& Institutional & 440 & 16.4 & 5.0 \\
\hline Recreational $^{\mathrm{C}}$ & 240 & 8.9 & 2.7 \\
\hline Utilities \& Parking & 70 & 2.6 & .8 \\
\hline Highways & 500 & 18.6 & 5.7 \\
\hline Developed Land & 2691 & 100.0 & $30.6 \%$ \\
\hline Open Land & $\underline{6141}$ & & $69.4 \%$ \\
\hline Total Land Area & 8832 & & $100.0 \%$ \\
\hline
\end{tabular}

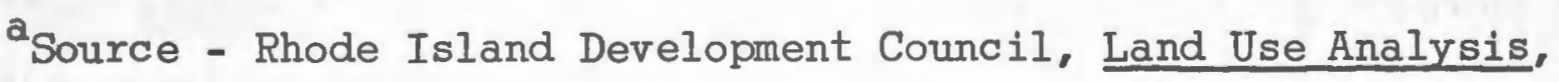
Table II, p. 9.

bIncludes Municipal, State, Federal, Religious and Semi-Public Land Uses.

${ }^{\mathrm{C}}$ Includes both Public and Semi-Public Land Uses.

(4) 3.08 people will live in each year round home (figure obtained by averaging 1950 and 1960 U. S. Census data for 
the number. of people per dwelling unit in Narragansett),

(5) the total developable acreage includes all land with no severe restrictions for development, and 500 acres of land with some development restrictions.

Using these assumptions, the saturation population at ultimate development can be estimated. The "1960 U. S. Census population will be used as a base since the 1962 land use data used in the population projection is most closely related to that Census. The saturation population will be calculated using the following equation:

Saturation Population $=$ Residential land acreage $\mathrm{X}$ dwelling density/acre $X$ ratio of year-round units to total units $X$ people/unit + 1960 Census Population.

The appropriate numerical quantities are listed below:

$$
\begin{array}{ll}
\text { Developable Land Acreage } & =4,491 \\
\text { Residential Land Acreage }(52 \%)(4,491) & =2,330 \\
\text { Dwelling Density } & =3 \text { units/ } \\
& \text { acre } \\
\text { Population (year-round) } & =3.08 \\
& \text { people/dwelling unit } \\
\text { Per cent of new units constructed will be year-round } & =70 \%
\end{array}
$$


Now, substituting these quantities in the previous equation yields: Saturation Population $=(2330$ acres $)(3$ units/acre $) \mathrm{X}$ (.70 year-round units/total units) X (3.08 people/unit)+ 3500 (1960 U. S. Census rounded off to higher 100)

Saturation Population $=15,000+3,500$ Saturation Population $=18,500$ people

Based on the estimated saturation population above, it would be fairly safe to assume that Narragansett will be saturated at a population of between 15,000 and 20,000 people. Of the total projected increase of 15,000 people, 3,686 people have already been accounted for by population growth between the 1960 and 1970 U. S. Censuses. Using a conservative population growth rate of 1,500 new residents every 10 years, the saturation population would occur about the year 2,045. Using a more liberal but probably more realistic growth rate of 2,500 people/year saturation population would be reached in only 45 years or about the year 2015.

Barring any major factors that would radically change existing demographic trends or differ markedly from the previous assumptions, Narragansett will be a fully developed suburban community of between 15,000 and 20,000 people within the next 50 to 75 years. 
The past sections of this report have related population, housing, and land use data to project the significance of these parameters for the town's future development. The following section will trace the methods which the public sector, primarily the town government, has used in the past to control the land development process and also the methods which are currently being considered.

\section{Public Development Policy}

Narragansett was incorporated as a Town in 1901.

Between that time and the passage of the "Narragansett Building and Zoning Ordinances" adopted by the Town Council, August 18, 1930, no town ordinance attempted to deal with the issue of land development on a comprehensive town-wide basis. The Ordinance also established minimum criteria for structures within the town and created the office of Building Inspector to ensure that these criteria were adhered to. 3 Other than certain amendments to the Ordinance, which will be discussed in detail, the intent and character of the Ordinance has remained essentially intact up to the present time. A new proposed zoning ordinance is currently urider discussion by the Town Council and the townspeople. Administrative structures were established by the

\footnotetext{
3 Town Clerk's Records, Narragansett Town Hall,
} Narragansett Building and Zoning Ordinance, 1931. 
town and ordinances pertinent to overall management were also passed as follows:

(1) Organization of a five member Planning Board in 1961,

(2) Adoption of subdivision regulations in 1965,

(3) Adoption of the following codes in 1967: electrical, plumbing, minimum housing, and fire prevention.

The town is governed by a five member Town Council and a full time Town Manager.

In addition to the steps taken above, several planning reports were performed by the Rhode Island Development Council. One of the most important documents, the Comprehensive Plan of 1967, was legally approved by resolution of the Planning Board and the Town Council in November of 1969. ${ }^{4}$

The purpose of the original zoning Ordinance was clearly established in Section I of that Ordinance. "The zoning regulations and districts herein set forth have been made in accordance with a comprehensive plan for the purpose of promoting the health, safety morals and general welfare of the community. They have been designed to:

${ }^{4}$ Mrs. Elvira Fayerweather, Assistant Town Clerk, Town Hall, Narragansett, Rhode Island, April 1972. 
- lessen congestion in the streets

- to secure safety from fire

- to provide adequate light and air

- to prevent the overcrowding of land

- to facilitate the adequate provision of transportation, water, sewage, schools, parks and other public requirements.

- and to promote the conservation of exceptional natural physical features.

They have been designed with reasonable consideration among other things to the character of the district and its peculiar suitability for particular uses, and with a view to conserving the value of buildings and encouraging the most appropriate use of land throughout the town." A more detailed discussion of the history and purposes of zoning is given in Chapter III of this study.

The original zoning ordinance approved in 1930 divided the town into five zoning districts:

Residence $A$

Residence B

Residence C

Business D

Commercial E

In a Residence $A$ district, the following uses were permitted:

(1) single family dwelling, hotel, 
(2) farm, truck garden, nursery, country estate,

(3) church, school, college, library, museum,

(4) golf course, polo grounds,

(5) private club which is not a business,

(6) philanthropic institution, hospital, or sanitorium,

(7) municipal water supply reservoir, tank, or filter bed,

(8) non-commercial park, playground, athletic field, bathing beach, bath house or boat house,

(9) government building,

(10) telephone exchange.

All uses permitted in the Residence $\mathbb{A}$ district are also permitted in the Residence $B$ district as well as twofamily dwellings and boarding or rooming houses. All uses permitted in the Residence B district are also permitted in. the Residence $\mathrm{C}$ district as well as multi-family apartments. In the business and commercial districts, any use is permitted which is permitted in a residence district. $A$. detailed listing of uses in these two districts will not be given. In general, Commercial E permitted uses are considered more undesirable than Business D uses. In Commercial $E$, certain industries are required to have special permits. 
Under Section 13 of the original Ordinance, the Town Council was also empowered to act as a Board of Zoning Review. The Ordinance stated the following: "When in its judgement the public convenience and welfare will be substantially served and the appropriate use of neighboring property will not be substantially or permanently injured, the Town Council acting as a Board of Zoning Review may in a specified case and subject to appropriate conditions and sáfeguards, authorize exceptions to the regulations herein established."

\section{Zoning Amendments}

An extensive review of town documents ${ }^{5}$ was undertaken to discover the degree to which land development policies as evidenced by amendments to the zoning Ordinance had changed since the drafting of the initial zoning Ordinance. Table V shows all the major amendments to the zoning Ordinanee (not including rezonings discussed later) up to the present. All the amendments involved related to lot sizes in residential districts. A major change was made in 1945 with the establishment of a new Residence AA district, which required a minimum of 40,000 square feet for a single-family dwelling. Except for a change in lot size required for an institutional use in a Residence $A$ district from 8 acres to 55,000

5 Town Clerk's Records, Narragansett Town Hall, Building and Zoning Ordinances. 
TABLE V

Lot Sizes in Residence Districts

Min. Lot.Size

Specified By Amended Second

Original Ord. Lot Size Date Amended Date

Zoning District

(square feet) (square feet) Amended Lot Size Amended

\section{Residence AA}

Single family dwelling or private club

None existed

40,000

$3 / 19 / 45$

Residence $A$ Single family dwelling or private club

Institutional ${ }^{a}$

Residence B

Single family or private club Two family

Institutional ${ }^{b}$

\section{Residence C}

Single family

Institutional ${ }^{c}$

Hotel or rooming house

$$
\begin{array}{r}
4,000 \\
6,000 \\
1 \text { acre }
\end{array}
$$

10,000
8 acres

15,000

55,000

$5 / 28 / 69$

$6 / 1 / 36$

10,000

$-$

$$
\begin{array}{r}
4,000 \\
6,000 \\
4,000
\end{array}
$$

$$
7,000
$$

$1 / 19 / 60$

10,000

20,000

$1 / 19 / 60$

$1 / 19 / 60$

\section{$1 / 19 / 60 \quad 10,000$}

$1 / 19 / 60 \quad 12,000$

$5 / 28 / 69$

10,000

$5 / 28 / 69$

apilanthropic institution, hospital, sanitorium or hotel.

${ }^{\mathrm{b}} \mathrm{Al}$ uses permitted in Residence $A$ as well as boarding or rooming houses.

${ }^{\mathrm{C}} \mathrm{All}$ uses permitted in Residence $A$ as well as telephone exchange 
square feet all lot sizes in Residence A, B and C districts have been upgraded at least once since 1930. In the Residence A district, requirements for single family lot size were upgraded in 1969 from 10,000 square feet to 15,000 square feet. Minimum lot sizes in the Residence B district for single family and two-family uses have been increased twice, once in 1960 and once in 1969. The minimum sizes for the uses shown in the Residence $\mathrm{C}$ district were also increased at the same time in 1960 as those in the Residence B district. In fact, all amendments relating to increasing minimum lot sizes in residence zones have occurred in the last twelve years or since 1960.

The previous data would seem to indicate the desires of townspeople and elected officials to prevent the proliferation of small lot sizes and the greater population density which results.

Required lot sizes for certain selected uses in the three residence districts are shown in Table V. Minimum lot sizes for a single family home ranged from 10,000 s.f. in a Residence $A$ district to 4,000 s.f. in a Residence C district. Whether incremental changes of this nature represent sound overall land use planning will be called into serious question by this study. However, this is not meant to be overly critical of the town's policy since their ability to enact sweeping land use reforms is constrained by several 
factors including the inertia which keeps certain political and administrative structures such as the zoning ordinance on a fairly unwavering course.

\section{Rezonings}

Rezonings, which are passed in the form of amendments to the zoning ordinance, are also indicators of public land use policy. An extensive review of all rezonings granted between the adoption of the original ordinance in August of 1930 and January of 1972 was undertaken. The data in Table VI summarize the results of this review.

The table lists six different classes of zone changes. These classes were determined following a complete tabulation of all amendments which were granted. Three of the six occurred so infrequently as to be of minor significance. The remaining three were of greater significance and will be discussed in greater detail.

Of the 108 total rezoning petitions granted, the vast majority (76) were requests to change from a residence district to a business $D$ district, the first class in the table. This class was the only one that had at least one or more zone changes in every five-year period. The number of rezonings occurring in the two remaining major classes were as follows:

(1) From a residence district to commercial 
TABLE VI

Types of Zone Changes Granted Over 5 Year Periods

\begin{tabular}{|c|c|c|c|c|c|c|c|c|c|c|}
\hline Classes of Zone Changes & $\begin{array}{l}1931 \\
1935 \\
\end{array}$ & $\begin{array}{l}1936 \\
1940 \\
\end{array}$ & $\begin{array}{l}1941 \\
1945 \\
\end{array}$ & $\begin{array}{r}1946 \\
.1950 \\
\end{array}$ & $\begin{array}{l}1951 \\
1955 \\
\end{array}$ & $\begin{array}{l}1956 \\
1960 \\
\end{array}$ & $\begin{array}{l}1961 \\
1965 \\
\end{array}$ & $\begin{array}{l}1966- \\
1970 \\
\end{array}$ & $\begin{array}{l}1971 \\
\text { Present } \\
\end{array}$ & TOTALS \\
\hline $\begin{array}{l}\text { From a Residence District } \\
\text { to Business "D" }\end{array}$ & 10 & 17 & 4 & 17 & 8 & 3 & 13 & 3 & 1 & 76 \\
\hline $\begin{array}{l}\text { From a more restrictive to } \\
\text { a less restrictive } \\
\text { residence district }\end{array}$ & & 2 & & 8 & 1 & 1 & 1 & 2 & 1 & 16 \\
\hline $\begin{array}{l}\text { From a less restrictive to } \\
\text { a more restrictive } \\
\text { residence district }\end{array}$ & & & & t. & & . & & 1 & 1 & 2 \\
\hline $\begin{array}{l}\text { From a residence district } \\
\text { to Commercial "E". }\end{array}$ & & & & 3 & 2 & 1 & 1 & 3 & & 10 \\
\hline $\begin{array}{l}\text { From Business "D" to } \\
\text { Commercial "E" }\end{array}$ & & & & 1 & & 1 & & 1 & & 3 \\
\hline $\begin{array}{l}\text { From Business "D: to } \\
\text { Residence "A" }\end{array}$ & & & & & & 1 & & & & 1 \\
\hline TOTALS & 10 & 19 & 4 & 29 & 11 & 7 & 15 & 10 & 3 & 108 \\
\hline
\end{tabular}


E-10,

(2) From a more restrictive to a less restrictive residence district - 16.

For the time period mentioned, no attempt was made to ascertain the number of petitions for rezonings that were actually filed; consequently, the number of zone changes desired was not determined. This type of investigation would have involved many hours of cross checking minutes of Town Council meetings with records of public hearings and was considered beyond the scope of the study.

In the two-year period from January 21, 1970 to January 19, 1972, a more thorough investigation of rezoning decisions including those involving denials was made. Three of these cases will be mentioned briefly to reveal the reasons behind the Town Council's decision to either grant or deny the zone change. One case, which arose in the summer of 1970, involved a petition for a zone change from Residence $A$ to Residence $C$ for the purpose of constructing garden apartments. The petition was denied primarily because of opposition from over fifty neighborịng property owners.

In the second case in October of 1971 a public hearing was held on a petition to change certain lots on Pt. Judith Road from Residence A to Business D for the purpose of constructing a dress shop and office building. This petition was denied since certain residents objected to 
further traffic congestion in the area and the addition of further business zones. The Planning Board was also against the rezoning since the master plan stated that the area should be primarily residential. The third case in August of 1971 involved a plan to construct retail commercial stores near the intersection of Point Judith Road and Woodruff Avenue. The change of zone from Residence $A$ to Business $D$ was approved by the Town Council. The positive factors behind approval of this rezoning were the generation of increased property tax revenue and the existing business use of surrounding properties.

Whether the policies of the Town Council were uniform in all cases, or whether similar criteria were applied to comparable classes of rezonings, could not be explicitly determined from the analysis. Since the original Ordinance offered the Council no real tangible criteria by which to judge rezonings and permitted considerable discretion in reviewing rezoning petitions, the probability is great that consistent and uniform treatment was not given to cases of a similar nature.

Two especially important conclusions can be drawn from the data compiled in Table VI:

(1) The original zoning ordinance did not allow sufficient areas for business or commercial uses. 
(2) To combat the inadequacies of insufficient business and commercial district, the zoning ordinance was interpreted liberally and resulted in a proliferation and dispersal of business zones throughout the Town.

The second conclusion deduced above is supported by a close inspection of the present zoning map on file at the Town Clerk's Office. Allowing the dispersal of business districts throughout the community instead of concentrating them in possibly two or three areas, certainly detracted from the viability of a well-planned business core in the downtown center known as the Pier Neighborhood. Hopefully, the 28 acre urban renewal project currently underway in the Pier area will remedy this situation and provide Narragansett with a much needed focal point.

A third conclusion can be arrived at from the data in the table concerning the reclassification of land from a more restrictive to a less restrictive residence district. The number of rezoning cases heard was too small to have a major impact on the town's overall land use policy.

\section{Zoning and Platting Board of Review}

On June 21, 1967, an amendment to Chapter 41, Section 13 of the Town's zoning ordinance was passed by the Town Council transferring the authority to grant variances and 
exceptions to the Zoning and Platting Board of Review as follows: 6 "There shall be appointed by the Town Council of the Town of Narragansett a Zoning and Platting Board of Review in and for the Town of Narragansett which shall consist of five members for a term of three years except that of the members first appointed, two shall be for a term of one year and two for a term of two years. Said Board shall in appropriate cases and subject to appropriate conditions and safeguards, make special exceptions to the terms of any ordinance enacted under the authority of Chapter 1277 of the Public Laws passed at the January Session, 1928 as amended, in harmony with its general purpose and intent and in accordance with general or specific rules therein contained, or where such exception is reasonably necessary for the convenience or welfare of the public. When in the judgment of said Zoning and Platting Board of Review, the public convenience and welfare will be substantially served and the appropriate use of neighboring property will not be substantially served or permanently injured, said Zoning and Platting Board of Review may, in a specified case, after public notice and hearing and subject to appropriate conditions and safeguards, authorize special exceptions to the regulations herein established."

${ }^{6}$ Ibid. 
A review of the records of the Zoning and Platting Board of Review was undertaken from the time of its establishment as a Board separate from the Town Council up until March 21, 1972. The tabulated results of that review are shown in Table VII:

\section{TABLE VII}

Decisions of Zoning \& Platting

Board of Review From 1967-1972

\begin{tabular}{lccccc} 
Year & Denials & Approvals & $\begin{array}{l}\text { Cases Not } \\
\text { Fully }\end{array}$ Traced & $\begin{array}{c}\text { With- } \\
\text { drawn }\end{array}$ & Totals \\
\hline 1967 & 2 & 2 & & & 4 \\
1968 & 1 & 2 & 1 & 4 & 3 \\
1969 & & 3 & 1 & & 5 \\
1970 & 1 & 3 & 8 & 1 & 23 \\
1971 & 7 & 7 & 7 & & 8 \\
1972 & & 11 & 17 & 1 & 47 \\
\hline TOTALS & 11 & 18 & & & \\
\hline
\end{tabular}

Of the total number of 47 cases, there were 18 approvals, 11 denials, 1 withdrawal and 17 cases not fully traced for a decision. Certain cases were not fully traced since this would have involved checking the individual hearing records for each case. In addition the information derived from these 17 cases would, in all probability, not differ vastly 
from the information gathered from the 30 cases, which were fully checked out. Cases heard by the Board were usually judged on the involvement of one or more of the following elements:

(1) effect on neighborhood or public welfare,

(2) existence of hardship,

(3) conformance with the current or future land use plan, and

(4) the character of adjacent properties. The majority of the cases before the Board involved applications for sideyard exceptions, or exceptions for building single family homes on undersized lots. Since the actual number of cases heard by the Board was small, the cumulative impact of their decisions on land use was not of major significance. However, if, for example, numerous variances or exceptions were granted to petitioners who wished to build on undersize lots, the net effect would be to increase the community's overall population density.

\section{Development Goals}

In a review of related documents only two were discovered which explicitly stated town-wide policy with respect to land use. The two documents, both prepared by the Rhode Island Development Council, were the Land Use Analysis (1962) and the Comprehensive Community Plan (1967). 
In the Comprehensive Plan, ten goals were forwarded based on the data and information contained in prior studies (Land Use Analysis, 1962; Circulation Study, 1964; Economic Base, Population, and Housing Study, 1966; and the Community Facilities Study, 1966). Of the ten goals, the following four goals had particular significance for land use policy:

(1) To further the welfare of the people in the Town by helping to create an increasingly better, more healthful, convenient, efficient, and attractive community environment.

(2) To provide for an attractive and desirable residential community realizing existing conditions and Town sentiment.

(3) To continue to provide and expand the necessary community facilities needed for community living, including educational and recreational facilities, utilities and an integral highway network.

(4) To provide new areas for the orderly growth of commercial, industrial research development, and the tourist industry to diversify and broaden the Town's tax base. 
Actual market forces may prevent the complete realization of these goals. To reconcile competing and conflicting interests which emerge from particular situations and to achieve positive developmental goals, both the townspeople and their elected representatives, the Town Council, will be called upon to establish clear cut and enforceable policy directions.

In fact within the context of providing desirable and effective land use planning, goal two above may pose severe problems. If it is to be regarded seriously, methods for implementing sweeping land use reforms, as discussed in Chapters II and III, may be extremely difficult to effectuate.

Five specific goals and objectives dealing with land use were delineated in the Land Use Analysis ${ }^{7}$ and later reiterated in the future land use section of the Comprehensive Community Plan. ${ }^{8}$ They are as follows:

(1) Preservation of a suitable residential environment in existing community areas.

(2) Encouragement of the types of development according to character and intensity of use which will make the Town a

\footnotetext{
${ }^{8}$ Rhode Island Development Council, Comprehensive
Community Plan, p. 23 .
}

p. 27.

${ }^{7}$ Rhode Island Development Council, Land Use Analysis, 
more "balanced" community in terms of land use development.

(3) Reservation of adequate areas for future residential, commercial, and industrial development and the enactment and administration of controls which will assure a proper separation of these uses.

(4) Encouragement of the tourist industry with continued development of beaches, marinas, tourist-oriented shops and accommodations.

(5) Encouragement of the development of waterfront fishing and boating facilities at Galilee and Jerusalem.

The Comprehensive Plan clarified what was meant in the second goal by the rather vague term "balanced" - "A community should contain, within its boundaries, areas devoted to each of a number of land use categories that are compatible and which will contribute to the viability of the Town's economic base. In achieving a "balance" of land uses, a community should provide:

- industrial or employment areas to provide opportunities for as many of its residents as possible;

* commercial areas to provide some of the goods and services for its population; 
- residential areas with a range of housing styles to satisfy the needs of various family types in terms of composition and income;

- recreational areas of various types; and

- wherever possible, open land areas in order to preserve the natural scenic beauty of the countryside."

The Land Use Plan advanced in the Cömprehensive Plan designated four residential zones of varying densities for development. A high density zone with 6 to 10 families per acre would contain single family, two family and multi-family structures. A medium density zone of 3 to 6 families per acre would encompass much of the seasonal housing, other single family housing, and some two family housing. The medium low density zone of 2 to 3 families per acre would be single family, and the low density ${ }^{9}$ zone of 2 or fewer families per acre would include large estates and farmland as well as single family housing.

The goals stated in the Plan illustrate the preoccupation as reflected in most zoning ordinances with protecting property values in residential areas and excluding "incompatible" uses from zoning districts. In many ordinances single family use is ranked preferentially as the

$$
{ }^{9} \text { Ibid, p. } 24 .
$$


highest and best use (see Critique of Zoning, Chapter III). Many communities especially suburban ones employ the technique of "fiscal zoning." Under this technique, a property owner's land is zoned in such a way that the owner will pay more for taxes than the town will pay for services rendered to the property owner. Narragansett itself is concerned with encouraging uses that will contribute positively to the Town's economic base. This situation is likely to continue as long as the property tax remains the primary source of revenue for local government.

\section{Proposed Zoning Ordinance}

The proposed zoning ordinance, currently under consideration by the Town Council and the citizens of Narragansett, has undergone several revisions since its initial draft in May of 1968. The revised zoning ordinance proposes to increase the number of zoning districts from the six allowed currently to ten zoning districts. Table VIII illustrates the approximate relationship of the proposed zoning districts to the current districts. Under the proposed plan, four residence districts would be retained, and the minimum lot size requirements for each residence district would also remain the same. For greater specificity the original business D zone would be subdivided into three business zones, and the original commercial E zone would be 
divided into two zones.

TABLE VIII

Relationship of Zoning Districts

\begin{tabular}{llr}
$\begin{array}{l}\text { Current } \\
\text { District }\end{array}$ & $\begin{array}{l}\text { Proposed } \\
\text { District }\end{array}$ & $\begin{array}{c}\text { Minimum Lot Size } \\
\text { (square feet) }\end{array}$ \\
\hline Res. AA & R-40 & $40,000($ single family) \\
Res. A & R-15 & $15,000(", "$ " $)$ \\
Res. B & R-10 & $10,000(", \ldots)$ \\
Res. C & R-10A & $10,000("$, \\
Bus. D & B, B-B, B-C & 20,000 \\
Comm. E & I-A, I-B & 20,000 \\
None & U-R &
\end{tabular}

An urban renewal district would be designated for the land in the Pier Neighborhood scheduled for redevelopment. The new ordinance is certainly more comprehensive and specific in detailing the uses permitted within each zoning district than the current ordinance. A whole new section on industrial performance standards has also been added. Under the new ordinance apartments would be allowed in all residence districts by special exception of the Zoning Board of Review, whereas under the existing ordinance apartments are allowed only in Residence C districts. However, in R-40 districts the one acre of land required per apartment unit would make the construction of apartments economically unfeasible. 
In comparing the zoning district maps for the current and proposed zoning ordinance, several important conclusions can be drawn:

(1) The location of existing zoning district boundaries had a major impact on determining the boundaries of zoning districts under the new ordinance.

(2) The designation of business and commercial districts also closely followed the existing business and commercial zones. Major concentrations of business and commercial use occur in the Pier Neighborhood, the University of Rhode Island Narragansett Bay Campus, and the State Piers at Jerusaleum and Galilee.

(3) An extremely large land area including a great deal of open space adjacent to the Narrow River was rezoned from Residence " $\mathrm{B}$ " and Residence " $\mathrm{C}$ " to $\mathrm{R}-40$, requiring 40,000 square foot iot sizes.

It can be inferred from Conclusion 3 that the Town sought to protect its open space by decreasing the density from 3 and 4 dwelling units per acre to approximately one dwelling unit per acre. Since districts are still provided for homes with minimum lot sizes of 10,000 and 15,000 square 
feet, this change would not necessarily be construed as exclusionary. The proposed ordinance does, however, treat one acre home sites preferentially, recognizing the positive effect which they normally have on the tax base of the community. This reclassification of land from smaller to larger lot sizes represents a fundamental change in policy from the existing zoning ordinance.

As in most zoning ordinances, both the existing and proposed zoning ordinance show a marked bias in favor of single family housing. The proposed ordinance is even more favorable in giving its blessing to large lot zoning. In general, large lot zoning is one of the most wasteful and land consuming mechanisms in existence in the market today. It confers a benefit on the. wealthy minority and deprives the vast majority the opportunity to enjoy the land, which was once an abundant resource.

Excluding the one fundamental policy change mentioned previously, it can be concluded that the effect the proposed zoning ordinance will have on the future growth and development of Narragansett will not be significantly different than the effect the existing ordinance would have assuming it were to remain in force.

- Recent Development Trends

The proposed zoning ordinance is being deliberated 
within the context of an uneasy and apprehensive political climate. In January of 1972 in response to aggressive development pressure, the Town Council approved a six-month moratorium on commercial and multi-family housing construction. ${ }^{10}$ Several large scale development proposals were advanced in 1971 ranging from a 350 unit condominium village and marina at Point Judith to the huge single family subdivision, Eastward Look at Scarborough State Beach, to a proposed fourteen store shopping center on Pt. Judith Road. Significant amounts of outside capital are pouring into the Town's real estate market. Town Manager, John Mulligan, has predicted that new buildings worth an estimated \$15 million will go up at the Pier in the next two years. ${ }^{11}$

Given this rapid rate of growth, it is not difficult to understand why the town fathers look to the new zoning ordinance as the panacea for all their problems. But the new zoning ordinance cannot and will not stop development. Nor is it or any zoning ordinance as presently conceived a very effective vehicle for positively shaping the form of development which many communities desire.

However, the Town is taking certain positive steps to plan for its future development. The Town is currently

${ }^{10}$ Narragansett Times, February 3, 1972.

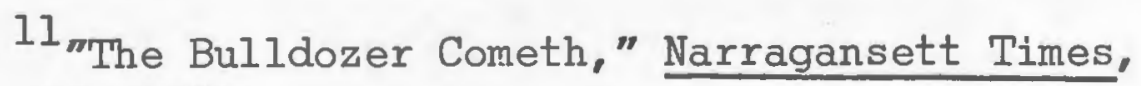
December 30, 1971. 
seeking to acquire the 225 acre Canonchet Farm property located adjacent to Narrow River and Narragansett Bay. If acquired, this would represent the largest single land acquisition in the history of the community. The majority of the property will be used for parks and recreation with the remainder being used for schools and municipal buildings . 12 The acquisition of land by the local government as a means of effecuating land use policy is discussed at*greater length in Chapters II and III.

The conclusions of this Chapter have tended to be pessimistic and rightfully so. If aggressive steps are not taken over and above a mere status quo revision of a zoning ordinance, the unique natural beauty of a community, which residents and visitors alike have grown to love, will be irretrievably lost. As developers gear up their machinery for progress, acres upon acres of sprawling pasture and scenic vistas will undoubtedly be consumed. In their place will come tracts upon tracts of monotonous, lackluster, and treeless subdivisions. Unfortunately, the same standardized techniques that were used to lay out the dull, dreary subdivisions of the past will in all probability be used in the subdivisions of the future.

\section{2 "Pier Asks Canonchet Farm Condemnation,"} Narragansett Times, March 16, 1972. 
It should be reiterated that no single town ordinance such as the zoning ordinance is the panacea for overall growth and development. The dynamics of the growth of a community are complex and involve a variety of interrelated variables. As the problem is extremely complex, the solutions are also complex. The time for Narragansett to take aggressive steps to plan for its future is now before its future becomes its past. Means for encouraging manageable community development will be discussed in the remainder of this study. Although the measures described have wide applicability, certain techniques can be applied in Narragansett. 


\section{EXISTING AND PROPOSED LAND DEVELOPMENT POLICIES IN THE STATE OF RHODE ISLAND}

In the preceding Chapter, the development and evolution of land use controls in the Town of Narragansett was traced. However, recognizing the significant interaction between state enabling legislation and local land use controls and ordinances, a study of this nature would not be complete without at least a brief description of land use controls on the state level. Accordingly, this Chapter will be devoted to an examination of existing and proposed legislation which attempts to influence land use in some manner.

Since communities are only empowered to enact land use controls enabled by existing state statutes, the degree of sophistication of local land use controls is directly related to the progressiveness and concern of the state legislature. In the past Rhode Island's track record in progressive land use legislation has not been outstanding, particularly, when it is compared to a pacesetter such as Hawaii, the first state to enact a comprehensive statewide land use policy. Hopefully, though, Rhode Island will follow closely the more progressive states in enacting 
contemporary land use legislation.

In considering land use legislation for Ris.sde Island, both on a state and local level, the existing political structure and the powers held by each level of government emerge as important parameters to examine. Consequently, the first section of this study will attempt to detail these two areas.

\section{Political Structure}

The state of Rhode Island is comprised of 39 units of primary government, 31 towns and 8 cities. In addition to the above, 56 units of special government are located in scattered districts throughout the state. The state is divided into five counties, which have no governmental powers and merely represent geographic boundaries. ${ }^{13}$

The preservation of town meeting form of government in 30 of the 31 towns mentioned previously has had a significant impact on the administrative structure of local government. Town meeting form of government evolved when the economies of these local communities was basically agrarian, and administration of government was a part-time function. With the increasing complexity of society, town government is gradually yielding to the use of full-time

13Edwin M. Webber, Rhode Island Local Government and Administration, Bureau of Government Research, University of Rhode Island, Research Series \#6, p. 7. 
professional administrators such as town managers, and the inadequacies of town meeting form of government become more apparent. Attendance at town meetings tends to be sparse and the public awareness in major issues also seems to be lacking. 14

Rhode Island, due to its density and compactness, is unique among the fifty states. It has been compared both to a regional city and to a large metropolitan area. The general mobility pattern is such that an individual could commute from his or her residence to almost any part of the state within a reasonable time. ${ }^{15}$ This geographical compactness represents a very positive factor when one considers implementing statewide development controls. In addition, the location of the capital city of Providence lends itself to the convenient administration of such programs and the city can serve as a central focus for the development and implementation of future programs.

The small size of the state and the sparse population of many outlying communities almost dictate that, for the economical provision of services, a regional approach to problem solving be taken. The two regional school districts currently in existence are examples of regional cooperation--

$$
\begin{aligned}
& { }^{14} \text { Ibid, p. } 27 . \\
& { }^{15} \text { Ibid, p. } 5 .
\end{aligned}
$$


Chariho Regional encompassing the towns of Charlestown, Richmond and Hopkinton, and Ponagansett encompassing the towns of Foster and Gloucester. 16

\section{Relationship of Power of State and Local Government}

Governments on the local level are creatures of the state and owe their substance to either the State Constitution, general laws, or special acts or resolves of the State Legislature. No inherent right to self-government, therefore, exists on the local level. 17 The famous "Dillon's Rule" defines the powers of municipal corporations (i.e. local governments) as "those granted in express words; second, those necessarily or fairly implied in, or incident to, the powers expressly granted; third, those essential to the declared objects and purposes of the corporation - not simply convenient, but indispensable. Any fair, reasonable doubt concerning the existence of power is resolved by the courts against the corporation, and the power is denied...."18 As an example of the pervasive powers given to the state, even though checks on the arbitrary use of this power are built

$$
\begin{aligned}
& { }^{16} \text { Ibid, p. } 10 . \\
& { }^{17} \text { Ibid, p. } 8 .
\end{aligned}
$$

${ }^{18}$ Daniel R. Mandelker, Managing Our Urban Environment (2d. Ed; New York: The Bobbs-Merrill Company, Inc., 1971), p. 97. 
into the State Constitution, the State may alter or abolish unilateraly charters of incorporation (R. I. General Laws, Chapter 45, Section 2-1). 19

Cities and towns as municipal corporations possess the power to tax, make contracts, and perform services normally expected of local government. ${ }^{20}$ Specific powers not strictly local in nature may be withheld by the state legislature, which continues to exercise jurisdiction in matters of general statewide concern. In case of disputes over whether state or local government has jurisdiction, the courts have generally ruled in favor of the state government. 21

Home Rule

Several communities in Rhode Island including Narragansett have adopted a home rule charter. Article 28, Section 1 of the Constitution of the State of Rhode Island expresses the intent of the home rule amendment - "It is the

19 Webber, Rhode Island Government and Administration, p. 8.

${ }^{20}$ Ibid.

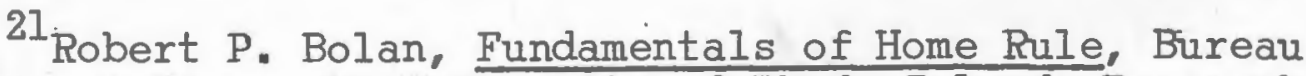
of Government Research, University of Rhode Island, Research series, \#l, p. 6. p. 10.

$22_{\text {Webber, Rhode Island Government and Administration, }}$ 
intention of this article to grant and confirm to the people of every city and town in this State the right of selfgovernment in all local matters." 22

Home rule is based on the concept of freedom of local governments to manage their own affairs. Complete home rale has never been realized since each city or town is subject to both the Federal and State Constitution, and other acts and resolves of both the Federal and State Legislatures. ${ }^{23}$ Several advisory opinions of the Rhode Island Supreme Court have also had the effect of weakening the home rule amendment to the State's Constitution. One Rhode Island case 8IRI258, 101 AtI(2d) 879 held that the General Assembly's power over local elections is exclusive and complete under Article 29, Section 7 of the Rhode Island Constitution. Other activities such as details of organization and functional responsibility of local government also fall within the domain of the State Legislature. ${ }^{24}$

Even with the above qualifying statements home rule cities or towns are still more independent of state rule than p. 10.

22 Webber, Rhode Island Government and Administration,

${ }^{23}$ Bolan, Fundamentals of Home Rule, p. 1.

${ }^{24}$ Webber, Rhode Island Government and Administration, p. 14. 
non-home rule cities or towns. The greatest authority which any home rule city may possess is as follows: the right to exercise all powers which the state legislature legally could have granted to the city before the adoption of home rule, whether or not they relate to local or municipal affairs. 25

\section{State and Local Powers.}

An understanding of the appropriate spheres of power of both state and local government becomes an important consideration in formulating any program including land use controls for these levels of government. In discussing the flow of powers from state to local government, two distinctions must be made between home rule cities and non-home rule cities. First of all, in home rule cities, power flows directly from the State Constitution to the people of the city and thence to the local legislative body. In non-home rule cities, power flows from the State Constitution to the State Legislature and thence to the local legislative body. With respect to the State Legislature, a second distinction exists between home rule and non-home rule cities. That is, the State Legislature must continue to pass general laws and special acts for non-home rule cities in the areas of jurisdiction

${ }^{25}$ Bolan, Fundamentals of Home Rule, p. 10. 
where home rule cities may act independently. ${ }^{26}$

\section{A legitimate question now arises: "How does a} community go about establishing a home rule provision?" Through the authority of the State Constitution the people of the potential home rule city elect a charter commission which in turn drafts a home rule charter. Once the charter is enacted, the home rule power normally resides in the city or town's legislative body. The charter commission still retains power to amend the charter, or modify, or withdraw any of the provisions of it. Of course, the local community is not empowered to enact provisions that would overlap or conflict with the authority of the state. Conversely, some State Constitutions prohibit the state from acting in matters of local concern and once the charter is approved by the General Assembly and is in force, the State Legislature cannot appropriate powers rightfully within the jurisdiction of the charter. Of course, conflicts do arise as to whether the state government or the local communities possess certain powers, which are not sharply defined, and the extent to which they are exercisable. A considerable amount of conflict could be avoided if it is remembered that "the State Legislature and the legislative body of a home rule city are equal and. co-ordinate agencies of the state exercising similar powers

$$
{ }^{26} \text { Ibid, p. } 13 .
$$


of the state within their respective areas of jurisdiction." 27

\section{Existing Land Use Control Measures}

Since existing legislation related to land use will influence future legislation, it is important to review, if only briefly, the current programs existing on the state level in Rhode Island.

Probably the most direct land use control, which a public agency can exercise, is direct acquisition by either condemnation or outright purchase.

Chapters 37-6 and 37-7 of the General Laws of Rhode Island create a State Properties Committee to regulate the acquisition, administration, and disposition of property by the state. ${ }^{28}$ As of May 1971, the state owned over 50,000 acres or approximately $8 \%$ of the state's total land area. ${ }^{29}$

A second piece of legislation passed by the General Assembly in 1964 the "Green Acres Land-Acquisition Act" (Chapter 32-4 of the General Laws) authorized the state to acquire land and to make grants to local communities to acquire land for recreation and conservation purposes. By the end of 1970 the state had acquired eleven sites, totaling

\section{${ }^{27}$ Ibid, p. 22 .}

${ }^{28}$ Rhode Island Statewide Planning, State Land Use Controls, (Unpublished draft report, 1971), p. 218.

${ }^{29}$ Ibid, p. 220. 
2,297 acres, while local communities had acquired 47 sites totaling 1,494 acres. 30 In order to receive aid local communities must conform to state regulations governing the administration, use, and development of the land.

\section{State Department of Health}

The State Department of Health is empowered by Title 23 (Department of Health) and Chapter 46-12. (Water Pollution) of the General Laws to adopt standards and regulations to prevent and control diseases and conditions detrimental to public health. These regulations have a major impact on development since a given site can only tolerate certain types and intensities of development and still meet appropriate air and water quality standards, sewage disposal standards, and related requirements. 31

The Health Department has several specific powers relating to sewage disposal. The Health Department must approve any proposed on-site disposal facilities and any proposed discharges into the waters of the state. Under a 1970 General Law (Section 23-27-6) municipalities may not grant a building permit unless the on-site method of disposal has been approved by the Health Department. In the case where a

\footnotetext{
${ }^{30}$ Ibid, pp. $221-222$.

${ }^{31}$ Ibid, p. 223.
} 
new development is to tie into the municipal sewer system, the Health Department could prevent the tie in if the sewage treatment plant did not have the capacity to treat the additional volume generated by the proposed development. 32

\section{Public Utilities}

Several state agencies are involved in the regulation of public utilities, but two state commissions are directly involved with decisions relating to utilities, which also have implications for land use. The first body, the Public Utilities Commission, was created in 1969 by Chapter 39-1 of the General Laws. The Commission was charged with the supervision and reasonable regulation of public utilities in order to conserve the state's natural resources, and to provide adequate energy sources, communication facilities, and water supplies with due regard for the strengthening of long-range land-use planning. The Commission has authority to act as a court of record and to make or enforce orders through the Superior Court. 33

The second Commission, the Atomic Energy Commission, established by Chapter 42-27, of the General Laws, is concerned with "the presence within the state of special nuclear materials and from the operation herein of production or

$$
\begin{aligned}
& { }^{32} \text { Ibid, p. } 224 . \\
& { }^{33} \text { Ibid, p. } 225 .
\end{aligned}
$$


utilization facilities." The Commission performs research and acts as an advisory body. 34

\section{Water Resource Protection}

Several laws have been passed in Rhode Island dealing with the protection of salt marshes, fresh water wetlands, coastal wetlands, and land along the shoreline.

A law protecting intertidal salt marshes was passed by the General Assembly in 1965 (Chapter 11-46.1 of the General Laws). Under the law, anyone wishing to alter the ecology of the marsh by filling or dumping material or by excavating material must obtain a permit from the State Department of Natural Resources. Violators are subject to penalties and may be required to restore.the marsh to its former state. 35

Another 1965 law (General Laws Section 2-1-13 and 2-1-17) declared it to be public policy to preserve the "purity and integrity" of coastal wetlands. A coastal wetland is defined as a salt marsh bordering on tidal waters and adjacent uplands not more than 50 yards inland from the marsh. This definition is not as restrictive as that applied to intertidal salt marshes. In a coastal wetland, only certain species of plants need to be found in the salt marsh,

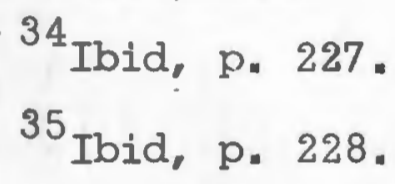


but in an intertidal salt marsh, salt marsh peat must be found in addition to certain species of plants. 36

The Department of Natural Resources in Rhode Island has the authority to designate and protect certain salt marshes and to establish uses which may or may not be permitted in the marsh. As a result of a 1971 state law, the Department of Natural Resources also has the authority to protect fresh water wetlands. The law prohibits excavating, draining, filling or dumping of certain materials without the approval of the Department of Natural Resources and the local governing body. 37

Other agencies with water resource related powers are the Department of Health, which must approve water supply sources and sewage treatment plants, and the State Water Resources Board, which must plan for the conservation and overall development of the state's water resources.

\section{Tax Relief for Open-Space Land}

In 1968 the legislature passed a law (General Laws Chapter 44-27) that would grant tax abatements to individuals who agreed to allow their land to remain in an open-space use. Thus, the law encourages the preservation of farm, forest, and open-space land and attempts to prevent the conversion,

$$
\begin{aligned}
& { }^{36} \text { Ibid, p. } 229 . \\
& { }^{37} \text { Ibid, p. } 229
\end{aligned}
$$


due to economic pressure, of this land to more intensive uses. 38

An owner who wishes to qualify for a tax abatement applies to his local tax assessor for a classification of his property as open-space land. If the assessor determines that the owner is eligible, he will assess the property strictly as to its present use, in other words, he will disregard adjacent uses of a more intensive nature in determining the value of the property. The tax abatement is cancelled if the land is converted to a more intensive use (not necessarily if it is sold), and a "roll back" tax becomes due. The "roll back" tax is due in the year of the change plus the two proceeding years in an amount equal to the difference between thetrue assessed value and the tax abated assessed value. 39

One disadvantage of this relatively short "roll back" period is that a land speculator may buy a property, walt for a ripe time to sell, and then realize a considerable profit. even after the "roll back" taxes are paid. The state is proposing a revision of the current system, which would replace the "roll back" tax by a 50\% state capital gains tax.

${ }^{38}$ Ibid, p. 233.

${ }^{39}$ Ibtd, p. 234. 
The tax revenues would be returned to the local community. ${ }^{40}$

\section{Historic Area Zoning}

Six cities and towns in Rhode Island have utilized the State Legislation (1959 General Laws, Sections 45-24.1-1 thru 45-24.1-7) authorizing municipalities to establish historic districts in a fashion similar to which municipalities outline zoning districts. The law proclaims that a public purpose is served by the preservation of structures of historic or architectural value. The law also enables the formation of local historic district commissions, which have the responsibility for reviewing plans pertaining to the physical development of the area.

\section{Housing and Redevelopment}

Housing authorities were created through Title 45 of the General Laws. Their stated purpose was "the clearance, replanning, and reconstruction of areas in which unsanitary or unsafe housing conditions exist and the provision of safe and sanitary dwelling accommodations for persons of low income." Housing authorities have a broad spectrum of power related to acquisition and eventual development of property to fill the housing demand. 41

$$
\begin{aligned}
& { }^{40} \text { Ibid, p. } 268 . \\
& { }^{41} \text { Ibid, p. } 236 .
\end{aligned}
$$


Minimum housing legislation, Chapter 45-24.2 of the General Laws, was enacted in 1962 and amended in 1968. Under the law city and town councils are authorized to establish and enforce regulations for minimum housing standards. 42

To reinforce the legislation mentioned previously, the General Assembly enacted the "Rhode Island Housing Maintenance and Occupancy Code" in 1970. Blighted housing is cited as a drain on public revenues. The code sets forth minimum standards for basic equipment and facilities, light, heat, ventilation, and other related variables: ${ }^{43}$

The Redevelopment Act of 1956 (General Laws, Chapter 45-31 thru 45-33) provided for the creation of redevelopment authorities to eliminate blighted and substandard areas. The legislation also enables local code enforcement projects and describes methods of financing activities as well as the type of activities to be carried out. ${ }^{44}$

\section{Industrial Land Bank}

The 1970 Rhode Island Land Development, Corporation Act' forms Chapter 37-18 of the General Laws. The purpose of the law is to reserve an adequate supply of land for the

$$
\begin{aligned}
& 42 \text { Ibid, p. } 237 . \\
& 43 \text { Ibid, p. } 238 . \\
& 44 \text { Ibid, p. } 239-41 .
\end{aligned}
$$


future economic expansion of commerce and industry. The corporation created by the legislation would have the power to acquire or lease land or equipment and to finance and construct buildings or related physical facilities. ${ }^{45}$

\section{Land Use Controls Along Highways}

The several state laws dealing with land-use controls along highways will only be mentioned briefly here. Chapter 37-6.2 of the General Laws, related to beautification along federally aided highways, enables the state to acquire strips of land along the highway for beautification purposes and to provide sanitary facilities for the travelling public.

Legislation was also passed (Chapter 24-10.1) regulating the placement and character of outdoor advertising, and controlling junkyards along highways. In both cases, the State Department of Transportation is responsible for enforcing the regulations. 46

\section{Official Map Techniques}

The authority for an official street map is derived from Chapter 45-23.1 of the General Laws, which permits communities where a planning commission exists to establish one. The official map indicates all existing streets and any streets which may not have been constructed but which are

$$
\begin{aligned}
& { }^{45} \text { Ibid, p. } 242 . \\
& { }^{46} \text { Ibid, p. } 245 .
\end{aligned}
$$


part of an approved subdivision. The purpose of the State Enabling Legislation is "to serve and promote public health, safety, moral, convenience, economy, orderliness and general welfare; to further the orderly layout and use of land; to stabilize the location of property boundary lines; to ensure proper legal descriptions; to facilitate adequate provision for transportation; and to facilitate further subdivision of large tracts into smaller parcels of land." The official map is a useful tool in appraising the growth and pattern of development of a community and should be used as a guide in implementing a future circulation plan for the municipality. ${ }^{47}$

\section{Flood Plain Controls}

One of the provisions of the Housing and Urban Development Act of 1968 established a National Flood Insurance Program to provide subsidized insurance to flood prone communities. Rhode Island began participating in a program in 1970 and as of October 1, 1971, twenty communities had met the necessary requirements. In order to be eligible for the flood insurance, a community must ensure through the enactment of appropriate ordinances that future development in flood prone areas will be designed to avoid or minimize the risk of flood damage. Under the legislation flood plain

${ }^{47}$ Ibid, p. 247. 
areas would include areas subject to flooding by storms, tidal action, overflowing riverbanks, or mudslides. ${ }^{48}$

\section{Coastal Resources}

In 1971 the General Assembly enacted legislation (General Laws, Chapter 46-23) to protect one of the state's most valuable resources, its coastal zone. The bill established a 17 member Coastal Resources Management Council, assisted in a staff capacity by the State Department of Natural Resources, to review developments affecting the coastal zone. The Council is charged with formulating plans, policies, and regulations in its area of jurisdiction, that is from the mean highwater mark to the seaward limit of the state's control. 49 Although the Council also has review power over any private proposals for the area, enforcement is based on the concept that the local government should be given the opportunity to act first. The Council has authority to issue cease and desist orders to violators and to force them to remedy their violation. 50

\section{Programs Currently Under Development}

Unioue Natural Areas

In 1971 a survey of unique natural areas in Rhode

$$
\begin{aligned}
& { }^{48} \text { Ibid, p. } 248 . \\
& 49 \text { Ibid, p. } 250 . \\
& 50 \text { Ibid, p. } 251 .
\end{aligned}
$$


Island was undertaken by the New England Regional Commission and the New England Natural Resources Center. With the survey as an initial background, areas threatened by commercial or residential development were identified and governmental and private actions were encouraged to preserve the threatened areas. 51

\section{Building Regulations}

Since 1970 the Legislature has been concerned with establishing a more coherent system of building regulations to replace the multitude of uncoordinated codes that currently exist. A committee was established in the same year to "study the feasibility of adopting a state model building code, including state mandatory building standards and the licensing of local building inspectors." 52

An act to regulate factory-built or mass-produced housing in order to simplify standards and establish uniform inspection procedures was also passed in the same year. The law enabled the State Department of Community Affairs to adopt and enforce regulations governing the factory-built housing. 53

\section{Subdivision and Zoning Controls}

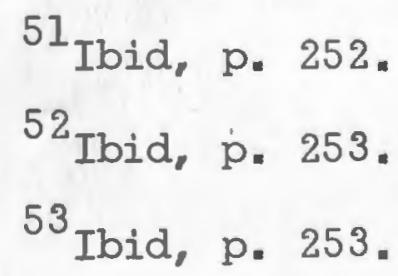


Legislation introduced in both the 1970 and the 1971 sessions of the general assembly proposes revisions to Chapter 45-23 (Subdivision of Land) and Chapter 45-24 (Zoning Ordinance) of the General Laws. The legislation regarding subdivision of land would include several amendments, the more important amendments dealing with limiting development of land subject to flooding and allowing subdivision flexibility for cluster and planned unit development. The legislative amendments proposed for zoning would significantly expand the purposes of local zoning ordinances. Among the expanded purposes would be:

(1) Promotion of maximum opportunity in housing for all social and economic classes.

(2) Promotion of a coherent open-space policy to prevent wasteful land practices and urban sprawl.

(3) Utilization of sound environmental planning standards for large scale land development.

(4) Adherence to policies of local comprehensive plans and the State guide plan. In addition to the general policy statements above specific controls are also proposed as follows. 54 
(1) Performance standards for noise, air and water quality, and various other environmental factors.

(2) Strict control of extractive industries such as sand and gravel.

(3) Restriction of harmful development in areas of outstanding ecological value.

(4) Regulation of signs.

Intermunicipal Zoning Board of Review

An act to create an Intermunicipal Zoning Board of Review has been introduced into several legislative sessions and would represent an addition to Title 45 of the General Laws. The jurisdiction of the Board would be within 500 feet of a municipal boundary. The board could hear an appeal when one of two neighboring communities was dissatisfied by a rezoning decision of the adjacent community's council or zoning board. In this instance the Intermunicipal Board could either affirm, modify, or nullify the decision of the local community. Passage of this act is significant. in that it moves away from the traditional philosophy of isolationism in which zoning applied only within each community. 55

${ }^{55}$ Ibid, p. 259. 


\section{Proposed Laws and Programs}

. This section will discuss proposed alternative programs, which are intended to foster a sound policy of growth and development.

\section{Fiscal Policy}

Fiscal policy is, of course, one of the most dominant parameters in shaping growth policy, although it is often neglected. The dependence of local governments on the outmoded property tax has been well documented. To illustrate this dependence, $63.5 \%$ of Rhode Island's municipal revenue was derived from the property tax in 1969. ${ }^{56}$ One of the fundamental questions of land use and land use regulation is the extent to which an area must rely on the health of its economic base to support itself. A further, perhaps irreconcilable question, is "Can planning policy be very effective given the potency of basically economic market forces and the predominance of the local property tax as a revenue producing source?" 57

Many proposals have been made for revising the present taxing system including greater reliance on personal

${ }^{56}$ Rhode Island Department of Community Affairs, Annual State Report on Local Government Finances and Tax Equalization, (Providence: 1970).

${ }^{57}$ Rhode Island Statewide Planning, p. 265. 
income and general sales taxes or "piggy back" taxes, forming regional or metropolitan tax districts, instituting state and local user charges for public facilities, and sharing federal revenues. 58

\section{State Official Map}

The purpose of local official maps was discussed earlier in this chapter. The Statewide Planning Agency has recommended that a state official map should be created which would incorporate all local official maps and indicate corridors or areas of future interest to the state such as public rights-of-way, areas required for statewide facilities, or areas scheduled for acquisition by various state agencies. The map would be prepared after consultation with appropriate local, regional, state and federal agencies. Land designated on the map could be ranked into three or four levels according to priority of acquisition. The land of highest priority would be bought either by direct purchase for future use or by eminent domain proceedings. If the state had no immediate use for the land, it could lease it for low intensity uses such as a playing field or a parking lot. 59

\footnotetext{
${ }^{58}$ Ibid, p. 264. ${ }^{59}$ Ibid, p. 269-71.
} 
Open Space Development Rights and Easements

Currently, Rhode Island law allows the acquisition by the State of development rights and easements for the following future land uses: transportation, utilities, recreation, and conservation. Both transportation and utilities easements and rights-of-way have been acquired in the past by the state. Recreation and conservation easements, eligible under the Green Acres Program, have also been acquired under that program. For example, under the Green Acres Program as of May 1971, the state had acquired 175 acres of recreation and conservation easements and 20 acres of utilities easements. 60

Further legislation should be enacted to protect property of historic value and also land along the urban fringe. Under the proposed historic easement provisions an owner would enter into a legal agreement with an appropriate state agency to keep his historic property in certain restricted or non-intensive uses. Restrictions could be written directly into the property deed and would be tailored to the particular objective sought. Currently; Rhode Island state law permits only a 30-year easement whereas under Federal Laws for historic landmarks no such time limit exists. An owner granted a historic easement would gain both federal and state tax advantages. Preventing high density 60. Ibid, pp. 272-73. 
development in an area of historic value would in most cases affect the revenue lost by granting such an easement. Many property owners may think that granting an easement to the state for a "tax break" is not a sufficient incentive to keep them from selling their land on the private market and realizing a significantly greater profit. ${ }^{61}$ The overall success of the program then might hinge on the State offering sufficient initial payments to the property owner to induce him to grant the easement.

The second area, mentioned previously, where development rights could be utilized is on the fringes of built-up areas. Property could be acquired by the State in these areas through eminent domain proceedings and the proceedings justified on the basis that the taking will serve the purpose of preventing urban sprawl and contribute to the public health and welfare. After state acquisition the land could be resold to a public or private development corporation. This method would have three distinct advantages: the timing and rate of growth could be controlled, the growth pattern could be coherent and condensed, and the provision of public facilities and utilities could be planned in a more logical manner. A revolving fund could be established so that when the State realized a profit from the sale of its real estate, the

${ }^{61}$ Ibid, p. 275. 
revenue could be used for further public investment. ${ }^{62}$

\section{Large Scale Development}

The construction of new towns in America such as Columbia, Maryland and Reston, Virginia and the construction of large scale developments such as Cross Keys in Baltimore, Maryland and Heritage Village in Southbury, Connecticut have proven the economic and political feasibility of such projects. The state of Rhode Island has identified several areas as suitable for such large scale development, and appropriate mechanisms should be developed (such as a public or a semi-public urban development corporation) to encourage such projects. New communities can provide several advantages such as more flexible use of land, economies of scale, provision of adequate recreation and open space, a diversity of housing styles, and a mix of social and economic groups. Development can be effectively staged to allow the orderly completion of one stage before permitting the developer to go on to the next stage. In addition, new towns or communities would also be eligible for federal funding under the Urban Growth and New Communities Development Act of 1970. ${ }^{63}$

This type of development has not as yet been attracted to Rhode Island primarily because enabling legislation does

$$
\begin{aligned}
& 62 \text { Ibid, p. } 277 . \\
& 63 \text { Ibid, p. } 287 .
\end{aligned}
$$


not exist to permit it. In fact, as of last year, State legislation did not allow for either cluster or planned unit development.

State Land Use Controls

The land use programs for states other than Rhode Island as well as the national land use program are discussed in detail in Chapter III. State land use policy should attempt to encourage a coherent but flexible development pattern without overriding the authority of local government except in certain critical areas. A primary objective should be the prevention of incompatible development. For development purposes, four possible land categories could be established based on the uses permitted, the density of population, and the necessary level of services. ${ }^{64}$ The four areas could be:

(1) urban areas,

(2) rural conservation areas,

(3) seasonal areas and,

(4) critical areas of statewide concern such as highway interchanges, mass transit terminals, airports, water supply sources, flood plains, and unique natural or historic sites.

${ }^{64}$ Ibid, p. 292. 
The four areas are very similar in scope and intent to the four areas described in reference to Bucks County, Pennsylvania in Chapter III.

Of course, necessary legislation to enable the four development areas would have to be enacted on the state level. The Statewide Planning Agency could establish a State Guide Plan, which would set forth standards for each of the four areas. The Plan would be adopted, amended; and administered by the State Planning Council. The Planning Council would review the policies and regulations of local governments for conformance with the Plan, and notify communities which did not conform to the Plan to take corrective action. If the community refused to comply, the Council would have the authority to override the local ordinance involved. 65

The regulatory measures which all levels of government enact to control growth and development have a minor impact when compared to direct government decisions to tax, to spend, or to invest money. By these direct decisions market forces are set in motion that outweigh the influence of regulatory mechanisms and consider them only as peripheral influences.

The past chapter briefly described a myriad number of existing and proposed governmental programs affecting the

${ }^{65}$ Ibid, p. 301-02. 
complex subject of land use. In actuality, the influence which the public sector can have on the use of land is minor when compared with that of the private sector. Public decisions often set in motion basically economic or market forces beyond their control. In fact in many cases these same market forces may act to retard, impede, or prevent the implementation of desirable planning policy. Indeed, an intelligent method of influencing the whole question of land use might be to identify "sensitive" or "tipping" points within the whole matrix of public and private decision making and to attempt to intervene at those points. Planners have reason to proceed with caution when tampering with such a complex system. But as traditional students of the land use bailiwick, planners must tamper with the complex system involved and lead us forward to a more coherent, orderly, and effective land use policy. 
III. TRENDS IN STATE AND NATIONAL

LAND USE POLICY

The thrust of recent land use legislation in the United States, strongly influenced by statewide zoning in Hawaii, has been directed toward transferring responsibility for land use control from the local governmental level to the state and national level of government. Dunham and Bosselman, the authors of the American Law Institute's Model Land Development Code, stated the case more strongly in their report - "total localism in the regulation of land development has become anachronistic, calling for imaginative recourse to the State's authority to safeguard values that ought not to be subordinated to competing local interests." 66 However, addressing the problem of land use control from a strictly intergovernmental coordination viewpoint may only be attacking the symptoms of a system which needs massive overhaul rather than sporadic patchwork. The root question seems to be "Within the context of the existing political and legal system what degree of control can the government

${ }^{66}$ Allison Dunham, and Fred P. Bosselman, A Model Land Development Code, Tentative Draft No. 3. (Chicago: American Law Institute, 1971), from foreward to the report. 
exercise over individually held private property?" Severe constitutional limitations exist to protect a property owner from what is considered arbitrary and unreasonable governmental abuse of power. Furthermore, the right of a landowner to use his property as he wishes is entrenched in English common law, which forms the cornerstone of our legal system's statutes on property law. A deep philosophical and psychological attachment to property and the privacy afforded by $\chi$ it pervades English tradition and (is) illustrated by the exclamation: "A man's home is his castle!" In many cases even though this conservative and individualistic stance toward property rights will exclude consideration of a larger public interest, the attitude is not likely to change vastly considering the tradition and inertia already behind it. Proposed governmental and legislative reform has been content to work within the existing framework and the resulting change has been of an evolutionary and not a disruptive nature. Although the author sympathizes with a more egalitarian concept of property rights and a radical reform of existing norms, current concentrations of wealth and power in American society dictate against any major revisions along these lines.

But rends are appearing in the once unruffled fabric of our social system. The widespread supporters of the current environmental movement cry out against the 
destruction which man is wreaking daily on his surroundings. This movement has lent credence to the philosophy that man is the steward of the earth and not its owner. Environmentalists understand that man is merely one link in a complex eco-system which is thrown into disequilibrium when he, as one element of that system, attempts to dominate, pervert, and control the other vital links. Consideration of short run economic benefit must no longer be the primary factor in determining the utilization of the earth's precious natural resources.

\section{Evolution of Land Use Controls}

Traditional land use controls currently being utilized in the United States evolved from legislation drafted in the 1920's by the U. S. Department of Commerce. The two basic statutes involved are the Standard State Zoning Eanbling Act and the Standard City Planning Enabling Act. This legislation authorized the creation of local planning commissions to regulate the use of private property through the enactment of appropriate ordinances. ${ }^{67}$ These local ordinances have assumed two basic forms: zoning ordinances and subdivision regulations. Zoning sought to establish districts where only compatible uses would be tolerated whereas subdivision regulations dealt primarily with the

${ }^{67}$ Ibid, Reporter's Introductory Memorandum. 
means for laying out and servicing particular land areas and lots. Consequently, for over 50 years zoning and subdivision regulations represented the primary methods by which the public sector attempted to influence the overall land development process.

\section{Critigue of Zoning}

Disregarding the secondary impact of subdivision regulations, zoning stands alone as the primary vehicle for land use control. The foremost purpose of zoning, to protect property values by eliminating incompatible uses, is achieved by allowing only certain permitted uses within each district. The regulations are restrictive and govern such things as lot size, building height, and the minimum distances of buildings from lot lines. Zoning alone does not promote sound development policy but merely attempts to prevent excessively poor development. Although zoning is a valid exercise of the police power of government, its purpose cannot be perverted to represent a taking of property without just compensation, which would violate the due process clause of the Constitution (Article V, Amendment V). A local community, once state enabling legislation delegates the power, has the option of deciding whether or not they wish to enact a zoning ordinance. Since the decision is of a local nature, ordinances can and do vary widely from one 
community to another. The zoning ordinance may not necessarily be in accordance with the comprehensive plan, assuming the community has one, or other regulations adopted by the community. However, sound planning dictates that the zoning ordinance should be revised if it is not in accordance with the master plan. Certain communities have given the master plan a more formal status by passing a resolution adopting it as a legal document. 68

Many cases exist in suburban communities of ineffectual land use planning. Suburban zoning ordinances encourage urban sprawl by designating large tracts of land for strictly single family development. Zoning districts designating one to one half acre minimum lot sizes are common in a multitude of cities and towns across the country. The hierarchal nature of ranking uses in the average zoning ordinance has designated this "single family" use as the highest and best use possible. Although this type of segregated use activity may protect property values, it does. not encouraǵe diversity or an integrated approach to land use planning on the neighborhood or the districit scale. Contemporary planning techniques are at least attempting to deal with this problem.

${ }^{68}$ John W. Reps, "Requiem for Zoning," Plarining 1964; (Chicago: American Society of Planning Officials, 1964). . pp. 59-60. 


\section{State Legislation Related to Land Use}

In recent years several issues have illustrated the inability of localized land use controls to provide a solution which would consider a wider or regional interest. In California the communities surrounding San Francisco Bay.were filling in the Bay area so rapidly that a very real possibility arose, if filling continued, that the Bay would become a river. In New Jersey failure of local communities to agree on a development plan for Hackensack meadows stymied the utilization of that area for many years. ${ }^{69}$ In the New Jersey case a state level commission was finally formed to regulate development of the meadows. 70

Hawaii

In 1961 Hawaii was the first of the fifty states to enact any type of far reaching land reform by vesting statewide powers in its State Land Use Commission (Hawaii Rev. Stat. \& 205, 1968). Subsequently, the Commission divided the state into four zones: urban, rural, agriculture, and conservation. County governments, which are powerful in

${ }^{69}$ Dunham, and Bosselman, A Model Land Development Code, p. 1.

$70_{\text {U.S., }}$ Congress, Senate, Committee on Interior and Insular Affairs, Hearings on S3354 to Amend the Water Resources Planning Act to Provide for a National Land Use Policy, Part I, 91 st Congress, 2nd Sess, , 1970, p.34l. 
Hawaii, were given substantial authority to delineate and enforce uses within the respective zones subject to general regulations of the State Land Use Commission. ${ }^{71}$

Vermont

Vermont, faced with intense pressure for residential and industrial development, passed legislation in 1970 establishing a State Board charged with adopting and administering a statewide land use plan (15l Vt. Stat. Ann. \&\&6001-091, Supp. 1970). The legislation stipulated that any development in excess of 10 acres required a special state permit. However, if a municipality has not adopted permanent zoning or subdivision regulations, any development of one acre or more required a state permit. ${ }^{72}$

\section{Wisconsin}

Wisconsin responded to development pressure along its picturesque waterways and shorelands by adopting a Shoreland Zoning Law (Wisc. Stat. Ann, 144.26, Supp. 1970). A 1960 statewide inventory had shown that the majority of the scenic landscape was adjacent to these critical areas. The Division of Resource Development administers the law Code, $\mathrm{p}=2$.

${ }^{71}$ Dunham, and Bosselman, A Model Land Development ${ }^{72}$ Ibid. 
which applies to land 1000 feet around lakes and 300 feet from rivers and streams. The Division also supervises counties to insure that they are progressing adequately toward shoreland zoning. 73

\section{Massachusetts}

The Massachusetts Zoning Appeal Act (40B Mass. Gen. Laws Ann. \&\&20-23) establishes a Housing Appeal Committee within the Department of Community Affairs. The Committee hears appeals from developers who have been denied local approval to build low income housing. The importance of this legislation lies in the establishment of a quasijudicial administrative body at the state level that can override local zoning decisions. ${ }^{74}$

\section{Maine}

Maine recently established a procedure requiring all large commercial and industrial developments to obtain a permit from the Environmental Improvement Commission. The statutes identify development having a state or regional impact. 75

$$
\begin{aligned}
& 73 \text { Ibid. } \\
& { }^{74} \text { Ibid. } \\
& { }^{75} \text { Ibid. }
\end{aligned}
$$




\section{National Land Use Policy}

The National Land Use Policy Act of 1971 introduced by President Nixon is illustrative of a trend toward transferring responsibility for administering land use controls to higher levels of government. The bill states that "present State and local institutional arrangements for planning and regulating land use of more than local impact are inadequate." 76 The primary purpose of the bill is to establish a national land use policy, to authorize the Secretary of the Interior to make grants to assist the States in implementing land use programs that will protect areas of critical environmental concern, and control the direction of growth and development of more than local significance. ${ }^{77}$ Specific areas delineated in the act as areas of critical environmental concern are as follows:

(1) Coastal zones and estuaries;

(2) Shorelands and floodplains of rivers, lakes and streams;

(3) Rare or valuable ecosystems;

(4) Scenic or historic areas;

${ }^{76}$ American Society of Planning Officials, "The National Land Use Policy Act of 1971, Planning Advisory Service, Memo No. M. 2, (Chicago: American Society of Planning Officials, 1971), p. 3. .

${ }^{77}$ Ibid. 
(5) Key public facilities which induce development of more than local impact such as any major airport, highway interchange, and major recreational lands and facilities;

(6) Development and land use of regional benefit - includes development for which there is a demonstrable regional need which will outweigh any restrictive or exclusionary practices of the local governments involved. 78

The states in administering their land use programs may use any one or a combination of the following techniques:

(1) State, establishment of criteria and standards subject to judicial review and judicial enforcement of local implementation and compliance;

(2) Direct State land use planning and regulation;

(3) State review of land use plans, regulations, and implementation with full powers to approve or disapprove. 
The bill authorizes 20 million dollars annually from 1972 through 1976 to assist states in developing and managing land use programs. Grants to the states for up to $50 \%$ of the cost of developing and managing these programs are available. Funds are to be allocated based on the state's population and growth, nature and extent of coastal zones, and other areas of critical concern. ${ }^{79}$ The overall administration of the program would be carried out by the Department of the Interior. The President is authorized to designate a Federal agency to administer guidelines for carrying out the law. This responsibility will probably be taken up by the Council on Environmental Quality. ${ }^{80}$

An important factor to note in the bill is that it does not require a statewide inventory of land use only a method for inventorying and designating areas of critical environmental concern. Zoning is not discussed at all directly or indirectly in the bill.

\section{Model Land Development Code}

The American Law Institute's Model Land Development Code proposes an enabling act to replace the Standard State Zoning Enabling Act and the Standard City Planning Enabling

$$
\begin{aligned}
& { }^{79} \text { Ibid, p. } 9 . \\
& { }^{80} \text { Ibid, p. } 2 .
\end{aligned}
$$


Act passed in the 1920's. The authors argue for the establishment of a State Land Development Agency and local Land Development Agencies. The State agency would establish policy direction while the local agencies would be primarily responsible for enforcement of those policies. An appeal can be taken by any aggrieved individual to a State Land Adjudicatory Board, which would decide the case based on the record before the local Land Development Agency. Since the initial decisions are made by the local governing body, the need for extensive state involvement in the administration of the program is minimized. Consequently, the State Land Planning Agency and the Adjudicatory Board will be able to concentrate on major issues and cases. The authors have in fact stressed that local governments should retain control over decisions of strictly local control by stating "at least $90 \%$ of the land use decisions currently being made by local governments have no major effect on the state or national interest." 81

The State Land Planning Agency undertakes comprehensive statewide or regional planning and has the following duties and responsibilities:

(1) Reviews land development regulations in "districts of critical state concern" that it designates. p. 5 .

${ }^{81}$ Dunham, \& Bosselman, A Model Land Development Code, 
(2) Participates in local hearings when a developer alleges he is proposing "development of state or regional benefit."

(3) Establishes criteria for large scale development and participates in hearings on proposals for such developments.

The three areas of concern roughly parallel those described in the National Land Use Policy Act discussed previously. The State Land Planning Agency also reviews local plans and notes any inconsistences with state plans. ${ }^{82}$

The Code recommends that Regional Divisions be established within the State Land Planning Agency to administer the land use programs in various regions of the State. This would eliminate the need for independent Regional Planning Agencies which are responsible primarily to local constituent governments and represent another bureaucratic layer interposed between state and local governments. The recommended. structure would also hopefully eliminate the lack of cooperation between different regional agencies in the same state since all planning would be done by regional divisions in the same central office. ${ }^{83}$

$$
\begin{aligned}
& 82 \text { Ibid, p. } 50 . \\
& { }^{83} \text { Ibid, p. } 51 .
\end{aligned}
$$


The Code establishes a consistent procedure for reviewing the following actions: ordinances of the local government, rules of the local and the State Land Development Agency, and orders of the local and the State Land Development Agency. Currently, no standard method is available for reviewing decisions of the various state and local agencies involved in the land development process. 84

The Code also recommends the creation of a separate "Long Range Planning Institute" since the substantial involvement of the State Land Planning Agency in individual land development decisions may make it difficult for that agency to provide long range planning and policy direction. ${ }^{85}$

\section{Plan for Bucks County, Pennsylvania}

The National Land Use Policy Act and the American Law Institute's Model Land Development Code are primarily concerned with development having a state or regional impact. The development plan for Bucks County, Pennsylvania, ${ }^{86}$ on the other hand, is more comprehensive and attempts to set

${ }^{84}$ Ibid, p. 97.

${ }^{85}$ Ibid, p. 52.

86 Maridelker, Daniel R., Managing Our Urban Environment, (2nd Ed., New York: The Bobbs-Merrill Company, Inc., 1971), pp. 1033-41. 
up a framework for guiding all development, especially land on the urban fringe. The framework implicitly realizes that timing the sequence of development and providing public facilities at the right time and place are two essential factors in the overall process. The report is also based on the assumption that resources of the county planning agency can best be utilized if financial and staff resources can be focused on channeling development into specific designated areas and attempting to channel it away from other areas. Private market forces are recognized as having a major impact on the development process and as such are to be channeled rather than redirected. The fundamental policy is to prevent scattered development and urban sprawl without discouraging development in general.

The plan proposes four development areas:

(1) Urban areas where there is little undeveloped land,

(2) Development areas where growth pressures are intense,

(3) Rural holding areas where much land is still in agriculture and forest, and development pressures are not intense.

(4) Resource protection areas where development would jeopardize natural, recreational, or historic resources. 
Under the development area concept full public services and utilities are planned for a five-year period with periodic reviews based on changing trends. Water and sewer lines and other public facilities are extended into the area before development occurs. Under this format a developer would know when the public sector is willing and able to provide the necessary public services. In rural holding areas development would be discouraged until market demand made the extension of public utilities and other public facilities feasible.

Unlike zoning which attempts to designate what the final and best land use should be, the development area concept makes no attempt to designate a final use for all areas. It merely attempts to designate final uses in development areas which are expected to develop within five years. Rural holding areas are put in a reserve category which does not attempt to judge what the final land use will be and which recognizes that public services cannot at that . time be provided economically. Resource protection areas can occur within any of these other development areás.

The methods for implementing these strategies will not be discussed here. However, state legislation will be needed to allow full use of the development area concept. 
Directions in Land Use Planning.

David Heeter in his report reviewing five major reports on land use ${ }^{87}$ cogently summarized the direction which land use should take in the foreseeable future as follows:

(1) The land use guidance system should be flexible, and dynamic rather than static and end state oriented, as is conventional zoning.

(2) Primary reliance should be placed on police power regulations to establish standards for and restraints on development.

(3) Police power regulations should be expanded to allow incentives to landowners to act in the public interest. Regulations ruling compensatory payments to affected landowners unconstitutional should be legalized.

(4) Public acquisition and disposition of land should be relied on rather than

${ }^{87}$ David Heeter, Toward A More Effective Land Use Guidance System, Planning Advisory Service Report No. 250, (Chicago: American Society of Planning Officials, 1969), pp. 7 - 8 . 
police power to achieve certain objectives.

(5) Land use should be treated as occurring in three stages: developing, developed, and redeveloping. Different techniques should be applied to each category above. This is similar to the plan mentioned previously for Bucks County, Pennsylvania.

(6) Only local governments which have met certain requirements should be allowed to plan for or control the use of land.

(7) One single local agency should be made responsible for all local ordinances and programs which guide the use, development, and occupancy of land. This agency would be responsible for the duties of the building inspector, the zoning board of appeals, the planning board, and one function of the local legislature amendments to ordinances related to land use.

(8) A state planning and review agency should be created to promote interests greater than those of local government. 
(9) The employment of land use controls for exclusionary purposes should be prohibited.

\section{Implementation Measures}

In order to achieve the objectives of the land guidance system discussed in the last section, government will. have to expand its current programs and accuire new and flexible powers. Three specific means by which more effective land use controls could be instituted are public acquisition and control, development incentives, and compensatory payments.

The report of the Canadian Task Force on Housing and Urban Development concludes that the only way local government can effectively control development is through acquiring, servicing, and reselling "all or a substantial portion of the land required for urban growth within their boundaries. ${ } 88$ The primary purpose of this policy would be to ensure an adequate supply of land for certain uses and to control the timing, location, and scale of development. Sites of regional importance could be reserved using this method. Public acquisition is, of course, bẹing utilized in many communities at the present time, however, it is not being done on a large enough scale to effect major impact. In order to generate 
sufficient capital to acquire land, a revolving land bank could be set up on the local level. Matching federal and state funds could be utilized. By this method a community could buy land in outlying areas, sell it at a profit when the time for development arrives, and use the appreciated capital for further investment.

Both Britain and Sweden have been more extensively involved in public acquisition than the United States. In Sweden high levels of revenue for acquisition are provided by loans available through the central government. Sweden also has developed a projected 10 year plan for the acquisition of public land.

In New York State the Urban Development Corporation has acquired land for three new towns and several smaller projects. Although the Corporation has the power to override local regulations and to employ eminent domain, it has been able to function well without using these powers.

- Private developers have been quite willing to work on UDC funded jobs, which they say are low risk projects.

Federal legislation is also beginning to authorize more funds for public acquisition. In 1970 legislation was passed to give federal guarantee assistance to state and local governments to finance land acquisition and improvements for new communities. Current legislation before 
Congress would authorize "state and metropolitan development agencies" to receive federal guarantee assistance for development activities approved by HUD, which would include land for other new communities. 89

Development incentives, another method currently being used to a limited degree, encourage desired private action that cannot be achieved through conventional regulations. As an example, a land developer may be granted a higher dwelling unit per acre density if, he agrees to dedicate a certain percentage of the land for a school or for open space. This technique is being used by many communities that have cluster or planned unit development provisions in their zoning ordinance. 90

A third type of mechanism compensatory payment is used as a means of legitimizing regulations that would otherwise be unconstitutional. Regulations are imposed on an individual's property and damages are paid to the owner in the amount which his property may have decreased in value due to the restrictions. The regulation could be used to place land in a holding zone and prohibit development.

${ }^{89}$ William J. Nicoson, "In Search of the Public Interest," Urban Land, February, 1972.

90 Heeter, Toward a More Effective Land Use Guidance System, p. 11. 
Another method of implementing the strategy would be to require landowners to choose between regulation without compensation and complete sale of their land. This gives an owner who has suffered serious damages the right to bring a suit in "inverse condemnation" proceedings. 91

${ }^{91}$ Ibid, p. 11. 


\section{BIBLIOGRAPHY}

American Society of Planning Officials. Flexible Development Regulations. Planning Advisory Service Report No. 216. Chicago: American Society of Planning Officials.

American Society of Planning Officials. Larid Development Ordinances. Planning Advisory Service Report No. 86. Chicago: American Society of Planning Officials.

American Society of Planning Officials. New Techniques for Shaping Urban Expansion. Planning Advisory Service Report No. 160. Chicago: American Society of Planning Officials.

American Society of Planning Officials. The National Land Use Policy Act. Planning Advisory Service Memo No. M. 2. Chicago: American Society of Planning officials, 1971.

Bacon, Edmund N. "Principles for an Urban Land Policy". Urban Land, April, 1971.

Bolan, Robert P.,Fundamentals of Home Rule. Bureau of Government Research, University of Rhode Island, Research Series \#l.

"The Bulldozer Cometh." Narragansett Times, December 30, 1971.

Carson, John. "A National Urban Growth Policy," Urban Land, February, 1972.

Domestic Council, Executive Office of the President. The President's 1971 Environmental Program: Toward More Rational Use of the Land. Book 2 of a three-part series. Washington: U. S. Government Printing Office, 1971.

Downs, Anthony. "Alternative Forris of Future Urban Growth in the United States." Journal of the American Institute of Planners, January, 1970. 


\section{BIBLIOGRAPHY CONTINUED}

Dunham, Allison, and Bosselman, Fred P. A Model Land Development Code, Tentative Draft No. 3. Chicago: American Law Institute, 1971.

Heeter, David. Toward a More Effective Land Use Guidance System: A Sumary and Analysis of Five Major Reports: Planning Advisory Service Report No. 250. Chicago: American Society of Planning Officials, 1969.

Mandelker, Daniel R. Managing Our Urban Environment. 2nd Ed. New York: The Bobbs Merrill Company, 1971. •

Nicoson, William J. "In Search of the Public Interest." Urban Land, February, 1972.

"Pier Asks Canonchet Farm Condemnation." Narragansett Times, March 16, 1972.

Reps, John W. "Requiem for Zoning," Planning 1964. Chicago: American Society of Planning Officials, 1964, pp. 56-67.

Rhode Island Department of Community Affairs. Annual State Report on Local Government Finances and Tax Equalization. Providence: 1970.

Rhode Island Development Council. Circulation Study, Narragansett, Rhode Island. Providence: February, 1964.

Rhode Island Development Council. Community Facilities Study, Narragansett, Rhode Island. Providence: June, 1966.

Rhode Island Development Council. Comprehensive Community Plan, Narragansett, Rhode Island. Providence:, March, 1967.

Rhode Island Development Council. Land Use Analysis, Narragansett, Rhode Island. Providence: November, 1962.

Rhode Island Development Council. Monograph, Narragansett, Rhode Island. Providence: June, 1969.

Rhode Island Development Council. Neighborhood Analysis, Narragansett, Rhode Island. Providence: July, 1968. 


\section{BIBLIOGRAPHY CONTINUED}

Rhode Island Development Council. Subdivision Control Study, Narragansett, Rhode Island. Providence: May, 1964.

Rhode Island Development Council. Zoning Study, Narragansett Rhode Island. Providence: May, 1960.

Rhode Island Development Council. Zoning Study, Narragansett, Rhode Island. Providence: May, 1969.

Rhode Island Development Council. Zoning Study, Narragansett, Rhode Island. Providence: May, 1970.

Rhode Island Statewide Planning. State Land Use Controls: Unpublished draft report, 1971.

Town Clerk's Records, Narragansett Town Hall. Building and Zoning Ordinances: (Black three-ring notebook).

Town Clerk's Records, Narragansett Town Hall. Narragansett Building and Zoning Ordinance, 1931.

U. S. Congress. Senate. Committee on Interior and Insular Affairs. Hearings on S3354 to Amend the Water Resources Planning Act to Provide for a National Land Use Policy, Parts I and II. 9lst. Congress, 2nd Session, 1970.

Webber, Edwin M. Rhode Island Local Government and Administration. Bureau of Government Research, University of Rhode Island, Research Series \#6. 